\title{
The Concept of Rational Behavior and the Problem of Learning from Error in Neoclassical Economics: With a view of the Austrian's Critiques
}

\author{
Masoud Mohammadi Alamuti ${ }^{1}$ | m.alamuti@imps.ac.ir
}

Received: 25/01/2021 | Accepted: 16/06/2021

\begin{abstract}
The concept of rational behavior has a significant role in economics and the analysis of market economy and general equilibrium. Moreover, there exists a logical relationship between the limits of rationality and learning from error. Through explaining the concept of rational behavior in neoclassical economics and its relationship with the rational expectation hypothesis this article addresses the following two questions: First, has the idea of learning from error played a role in the formation of the neoclassical concept of rational behavior? If not, secondly, can this idea play a role in improving the meaning of rational behavior in economics? In response to these questions, the article goes through the following discussions: (a) the neoclassical concept of rational behaviors is reviewed and the critiques of behavioral economics and the theories of choice under uncertainty are discussed, (b) the rational usage of information and its relationship with the meaning of rational behavior are examined, and in this context, the importance of the idea of learning from error is explored, and (c) Karl Popper's theory of rationality as openness to criticism and its consequence for the idea of learning from error in terms of conjecture and refutation will be discussed. The article finally uses the Austrian economists', i.e. Hayek and Krizner, critiques regarding the neoclassical concept of rational behavior in order to demonstrate that Popper's theory of rationality can improve the concept of rational behavior in economics.
\end{abstract}

\footnotetext{
Keywords: Neoclassical Economics, Rational Behavior, Behavioral Economics, Openness to Criticism, Learning from Error, General Equilibrium, Austrian School, Karl Popper.
}

JEL Classification: B25, B13, D50, D83. 


\section{مفهوم رفتار عقلايى و مسئله يادكَيرى از خطا در

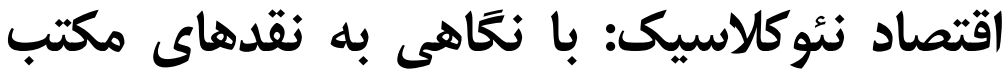 اتريشى افتى}

m.alamuti@imps.ac.ir

مسعود محمدى الموتى

استاديار كروه اقتصاد و سيستمهاى موسى الموتى موسه عالى آموزش و يروهش مديريت و برنامهريزى، تهران، ايران.

קُ جكيده: مفهوم رفتار عقلايى براى علم اقتصاد و توضيح آن درباره سازوكار (مكانيسم)

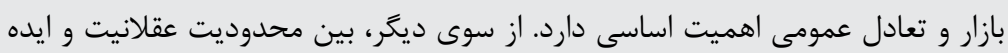

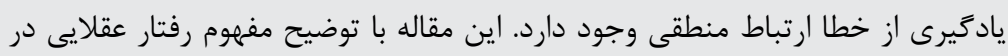

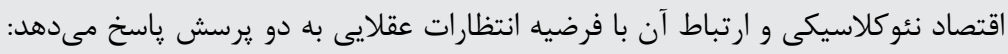

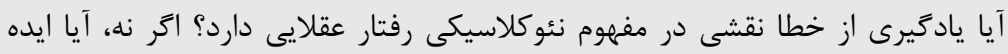

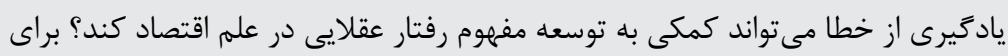

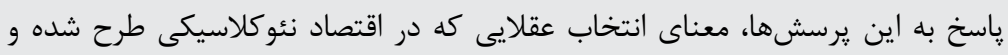

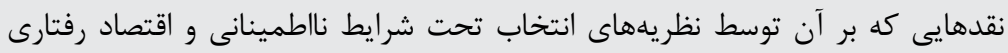

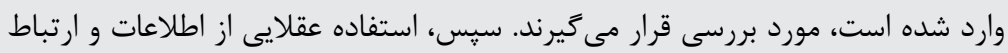

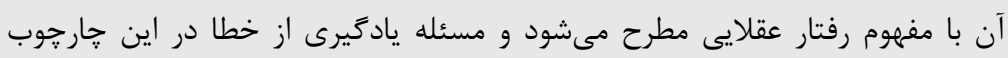

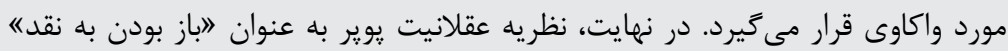

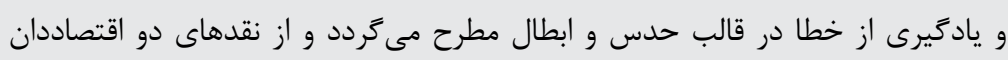

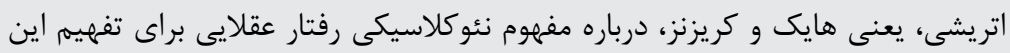

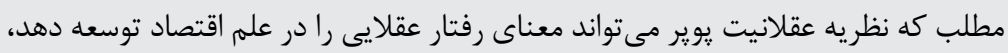
بهره كرفته مىشود.

كليدوازهها: اقتصاد نئوكلاسيكى، رفتار عقلايى، اقتصاد رفتارى، باز بودن به نقد، يادگيرى از خطا، تعادل عمومى، مكتب اتريشى، كارل يوير.

طبقدبندى D83, D50, B13, B25:JEL. 


\section{مقدمه}

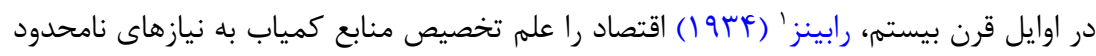
تعريف كرد. اقتصاد نئوكلاسيك اين تعريف از علم اقتصاد را پذيرفته و اساس تحليل سازوكار بازار

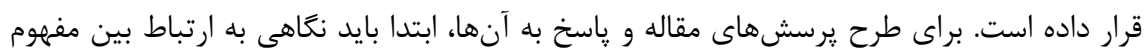

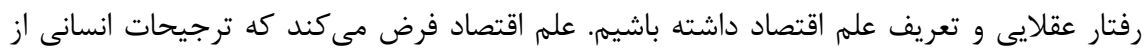
هر جامعهاى به جامعه ديگر مىتواند متفاوت باشد، اما ترجيح مطلوبيت يا سود بيشتر بر كمثرتر

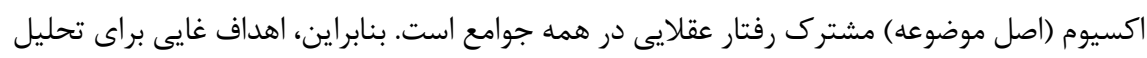
اقتصادى يارامترى برونزاست و تمركز تحليل اقتصادى بايد به حل مساله تخصيص منابع كمياب به هوهيه

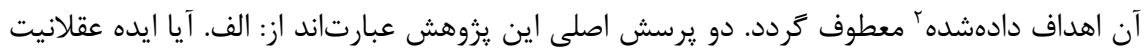

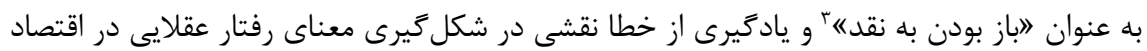

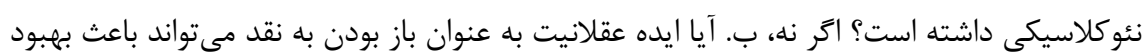

$$
\text { معناى رفتار عقلايى در علم اقتصاد كردد؟ }
$$

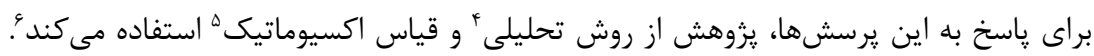

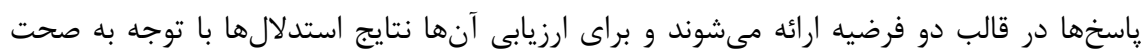

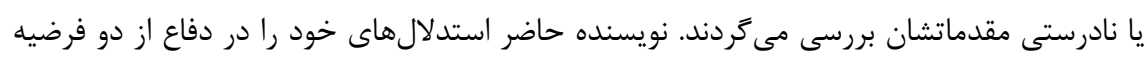
پيشنهادى درباره شكل گيرى مفهوم رفتار عقلايى در اقتصاد نئوكلاسيك و ييامدهاى آن براى توضيح

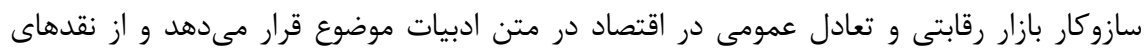

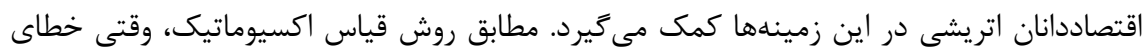

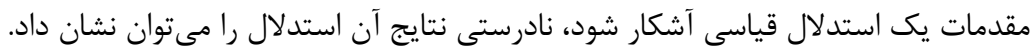

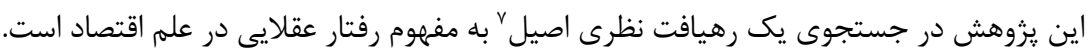

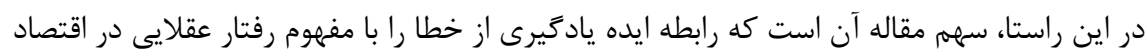

\section{Robbins}

2. Given Ultimate Goals

3. Openness to Criticism

4. Analytical Method

5. Axiomatic Deduction

צ. قياس اكسيوماتيك به آن استدلال قياسى كفته مىشود كه در آن صحت نتايج استدلال قياسى در نهايت

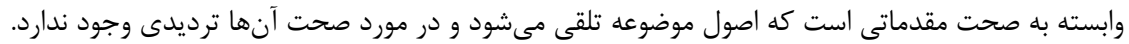
7. Original Theoretical Contribution 
نئوكلاسيك مورد واكاوى قرار مىدهد و استدلال مى كند كه اين خطانايذير فرض كردن تصميمات

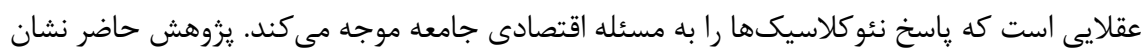

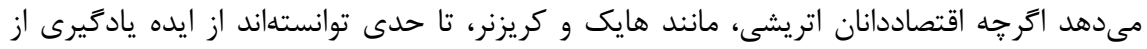

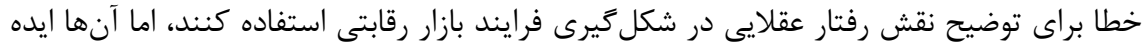

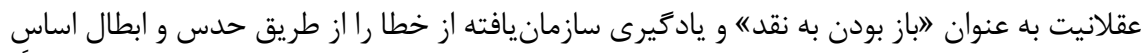

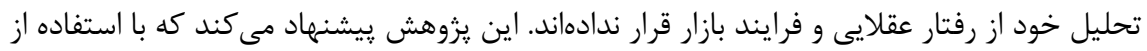
نظريه عقلانيت يوير' مىتوان ايده يادكيرى از خطا را وارد تعريف رفتار عقلايى در علم اقتصاد كرد.

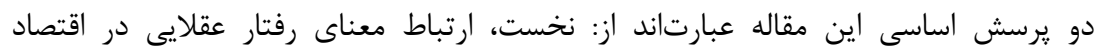

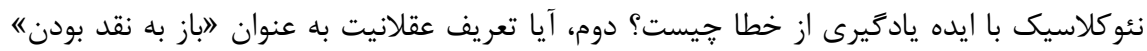

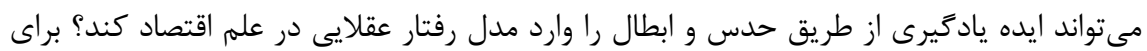

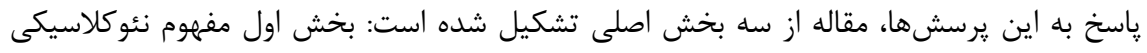

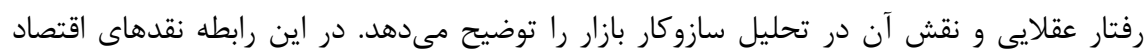

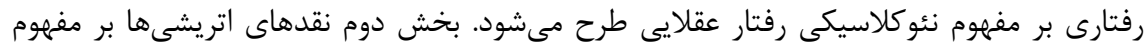

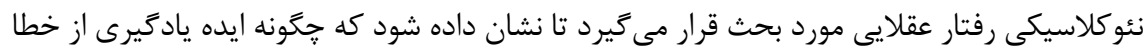

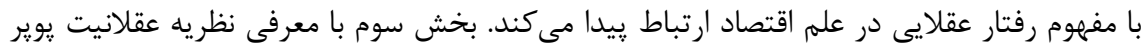

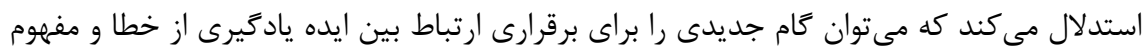
رفتار عقلايى در علم اقتصاد برداشت.

\section{مبانى نظرى يزوهش}

\section{مفهوم نئوكلاسيكى رفتار عقلايى و سازوكار بازار رقابتى}

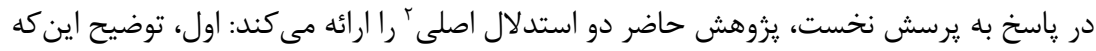

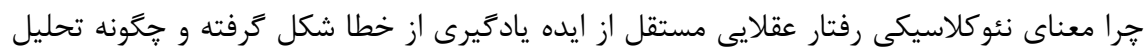
نئوكلاسيكى سازوكار بازار را تحت تاثير قرار داده است. دوم، ايده يادگيرى از خطا جگگونه با فرضيه انتظارات عقلايى، كه براى توضيح انتظارات از آينده ارائه شده، ارتباط ييدا مى كند. 


\section{مفهوم نئوكلاسيكى رفتار عقلايى و كاركرد سازوكار بازار}

در مقاله نظريه اقتصادى و فرضيه عقلانيت، آرو' (•99 ()) مى گويد: النظريه اقتصادى همواره بر فرضيهاى درباره عقلانيت تكيه داشته استه (YV). براى درك مفهوم رفتار عقلايى در اقتصاد

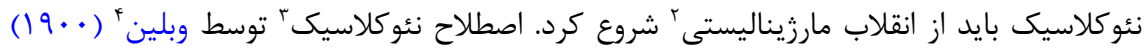
ابداع شد تا نشان دهد كه اقتصاد نئوكلاسيكى وجه تمايز مهمى با اقتصاد كلاسيكى دارد و انقلاب مارزيناليستى معرف اين وجه تمايز است. بررسى انقلاب مارزيناليستى ما را با مفهوم نئوكلاسيكى رفتار عقلايى و نقش آن مفهوم در توفيق نئوكلاسيكها براى اثبات وجود يك وضعيت تعادل عمومى ماريى در اقتصاد آزاد آشنا مى كند (Morgan, 2015). بنابر اين، با توضيح انقلاب مارزيناليستى مى تونوان فرضيه نخست يروهش، يعنى استقلال مفهوم نئوكلاسيكى عقلانيت از ايده يادكيرى از خطا را بررسى كرد.

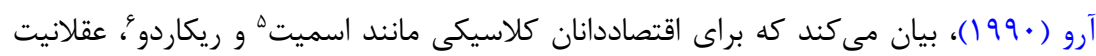
مفهوم محدودى داشت: "اترجيح بيشتر بر كمتر)، سرمايهداران آن صنايعى را تامين مالى مي كنيند كه نرخ بازدهى بيشترى داشته باشد و صاحبان زمين املاك خود را به قيمتهايى اجاره مى مهند

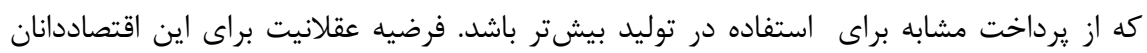

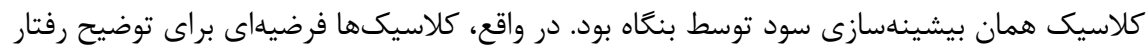

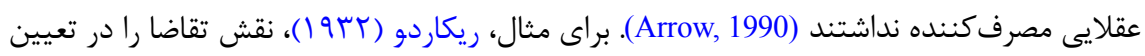

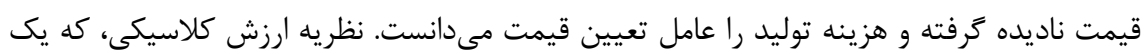

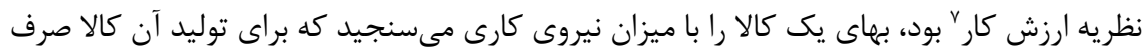

بهتدريج در ميان اقتصاددانان اين توجه يیدا شد كه تقاضا براى يك كالا نيز بايد نقشى در تعيين

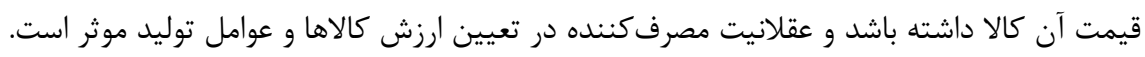
در واقع، انقلاب مارزيناليستى يك كذار از نظريه ارزش كار كلاسيكى، مبتنى بر عقلانيت توليدكننده، به يك نظريه ارزش جديد مبتنى بر عقلانيت توليدكننده و مصرفكننده بود. نظريه مطلوبيت نهايى

\section{Arrow}

2. Marginalist Revolution

3. Neoclassic

4. Veblen

5. Adam Smith (1723-1790)

6. David Ricardo (1772-1823)

7. The Labour Theory of Value 
ارزش' نظريهاى بود كه ارزش يك كالا را به اندازه فايده نهايى آن كالا براى تحقق ترجيحات ذهنى افراد مى دانست.

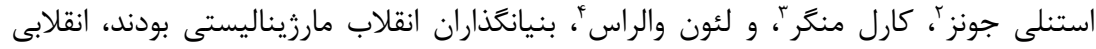

كه زمينه شكل

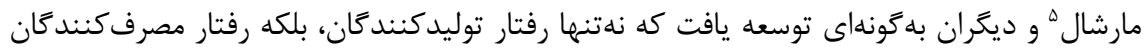

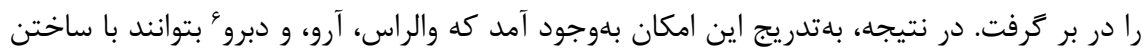

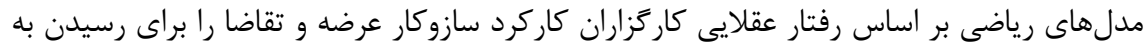

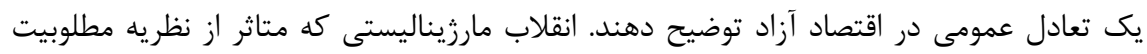

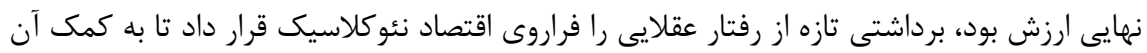
بتواند نهتنها انتخاب عقلايى مصرفكنندگًان، بلكه انتخاب عقلايى توليدكنندًان را در خار جوب يك فرضيه واحد رفتار عقلايى توضيح دهد.

مارزيناليستها از نظريه مطلوبيت نهايى ارزش براى توضيح اهميت تقاضا در تعيين قيمت يك لهـئ كالا استفاده كردند. اين نظريه مطلوبيت نهايى ارزش بود كه زمينه را براى تعريف رفتار عقلايى در

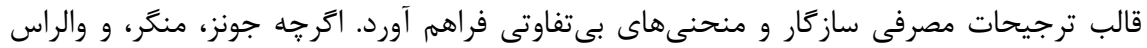

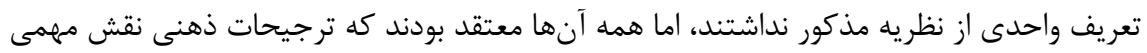
در تحليل رفتار عقلايى در علم اقتصاد دارد.

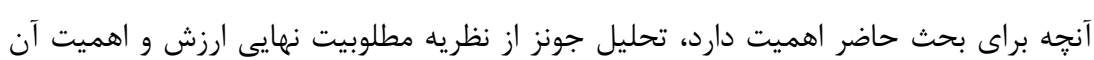
براى مفهوم نئو كلاسيكى رفتار عقلايى است. اين مفهوم عقلانيت توسط ديخر اقتصاددانان نئو كلاسيك مانند مارشال، والراس، آرو، و دبرو براى تحليل سازوكار بازار و اثبات وجود يكى تعادل عمومى در

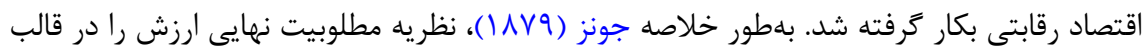

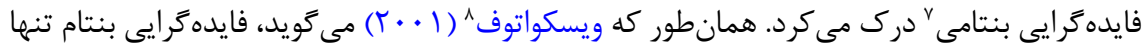
زمانى وارد اقتصاد نئوكلاسيك شد كه جونز و والراس آن را به يك نظريه مطلوبيت نهايى ارزش تبديل

1. The Marginal Utility Theory of Value

2. Stanley Jevons (1835-1882)

3. Karl Menger (1902-1985)

4. Leon Walras (1834-1910)

5. Alfred Marshall (1842-1924)

6. Debreu (1921-2004)

7. Bentham's Utilitarianism

8. Viskovatoff 
كرده بودند. جونز (1^V9)، استدلال كرد كه بايد نقش تقاضا براى يك كالا را در تعيين قيمت آن بر اساس فايدهاى كه آخرين واحد مصرف آن كالا نصيب فرد مى كند، توضيح داد. با الهام از تحليل جونز (1) (1)، درباره نقش ترجيحات ذهنى در تعيين قيمت كالاها، مارشال

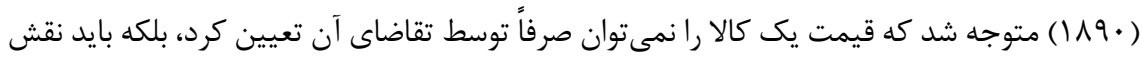

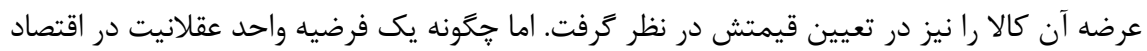
نئو كلاسيك براى توضيح شكل گيرى قيمت در بازار شكل گرفت؟

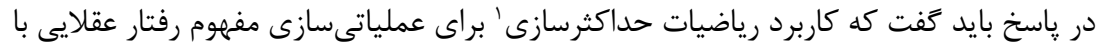
توجه به نظريه مطلوبيت نهايى ارزش بود كه مفهوم نئوكلاسيكى رفتار عقلايى را شكل داد. توضيح

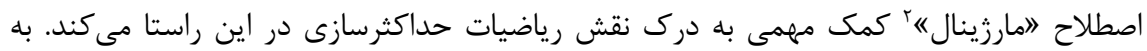
لحاظ رياضى، اصطلاح مارزينال براى واحدهاى نهايى بكار مىرود كه تحليل آنها براى تعيين روند

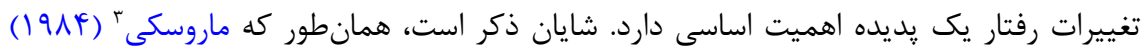
در فيزيك و انقلاب مارزيناليستى مى گويد، اصل حداقل تلاشَ بدان معناست كه وقتى تغييرى در

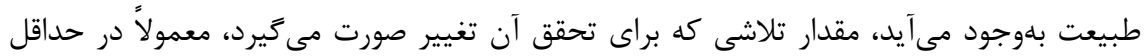
ممكن است. مارزيناليستها از اين اصل براى تحليل كنش اقتصادى به مثابه يك حركت استفاده كردند. اصل حداقل تلاش به فيزيك و اقتصاد در تعيين يك مسير خاص حركت (كنش) در ميان مسيرهاى مختلف ممكن، يعنى مسيرهاى حداكثر يا حداقل كمك اساسى كرد. اما نبايد فراموش كرد كه اين تحليل رياضى در علم فيزيك براى توصيف مسيرهاى حداكثرى يا حداقلى در حركت يديدهاى استفاده مىشد، كه دسترسى به عقل محدود عاملى براى بروز خطا در تشخيص نقاط حداكثر يا حداقل بلشمار نمى آمد (Koslowski, 1990).

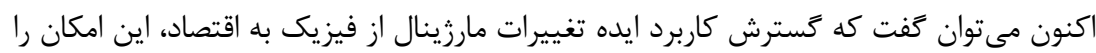
براى نئوكلاسيكها فراهم آورد كه براى توضيح رفتار عقلايى به مثابه حركتى يويا در جستجوى سود يا مطلوبيت بيشتر، بتوانند از منطق رياضى واحدى استفاده كنند. اين منطق رياضى حاكم بر قوانين حركت يديدهها بود كه امكان ارائه فرضيه واحد عقلانيت را براى نئوكلاسيك ها فر فراهم آورد، تا نهتنها رفتار عقلايى مصرف كننده، بلكه رفتار عقلايى توليدكننده را به استفاده از حساب تغييرات نهايى توضيح دهند.

1. Mathematics of Maximization

2. Marginal

3. Mirowski

4. The Principle of Least Efforts 
به علاوه، آنها توانستند اصول مطلوبيت و بازدهى نهايى را نيز بر اساس ايده تغييرات نهايى ارائه كنند. كاربرد منطق رياضى يادشده براى توضيح رفتار عقلايى در اقتصاد نئوكلاسيكى بدين معناست

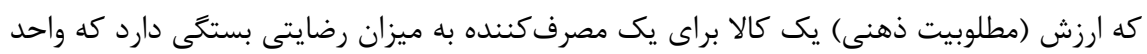

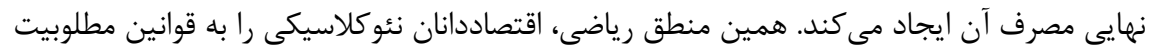
و بازدهى نهايى نزولى هدايت كرد كه براى تحليل رفتار عقلايى مصرفكننده و توليدكننده اهميت

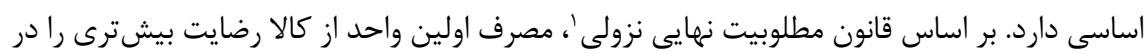

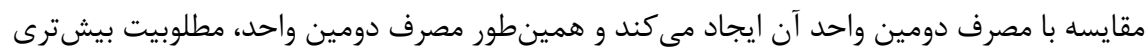
را در مقايسه با مصرف سومين واحد، و اين روند تا جايى ادامه يِيدا مى كند كه مطلوبيت نهايى آن كالا

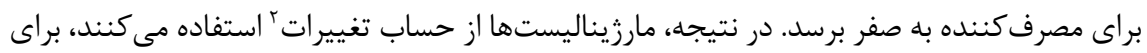

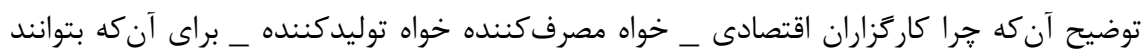
به هدف حداكثر مطلوبيت يا سود برسند، از قوانين مطلوبيت و بازدهى نهايى نزولى بيروى مهى كنند.

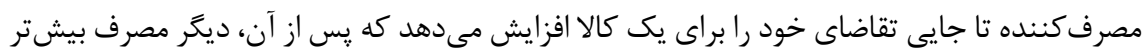

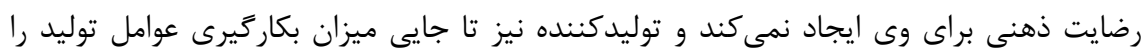

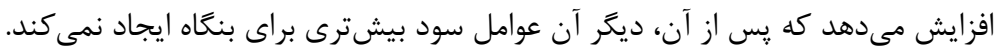

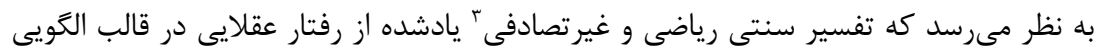

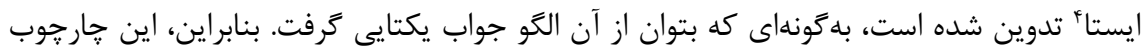

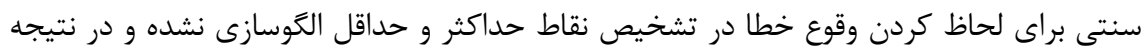
جايى براى يادگيرى از خطا نداشته است. البته توسعه نظريات در قالب اقتصاد نئوكلاسيكى به اين

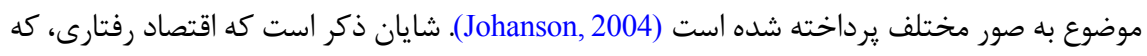
از داخل جريان اقتصاد نئوكلاسيكى مفهوم سنتى رفتار عقلايى را نقد كرده، نشان داده كه تصميمات

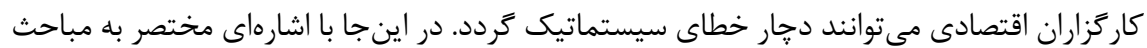
اقتصاد رفتارىه در رابطه با معناى رفتار عقلايى، ارتباط آن با ايده يادكيرى از خطا مورد توجه قرار

1. Diminishing Marginal Utility

2. Calculus of Variations

3. Non-Stochastic (Deterministic)

5. Behavioral Economics 


\section{اقتصاد رفتارى و معناى رفتار عقلايى}

هدف اصلى بحث حاضر آن است كه نشان دهد جُخونه اقتصاد رفتارى مفهوم نئوكلاسيكى رفتار عقلايى را از ديدگاه روانشناختى مورد نقد قرار مىدهد و ارتباط اين نقدها با نقش ايده يادگيرى

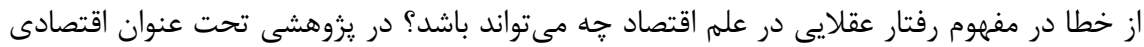

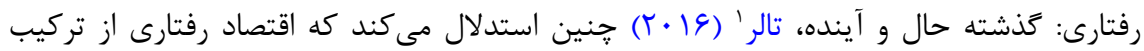
روانشناسى و اقتصاد شكل گرفته است. اقتصاد رفتارى برداشت نئوكلاسيكى رفتار عقلايى را در

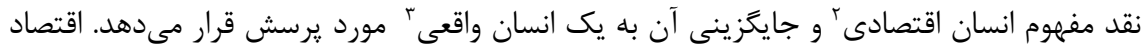
رفتارى مى گويد كه انسان واقعى در تصميمَّيرى خود با محدوديتِ شناخت و در نتيجه با ناطمينانى

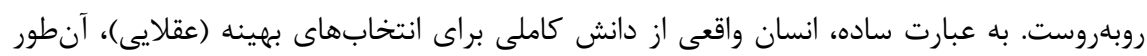

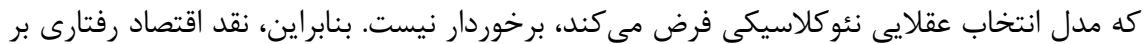

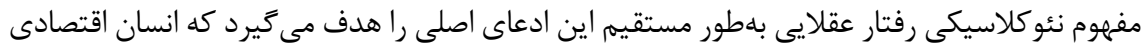

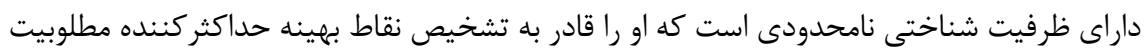
و سود خود مى سازد. به عبارت ديكر، برخلاف مفهوم نئو كلاسيكى رفتار عقلايى، انسان واقعى از منظر

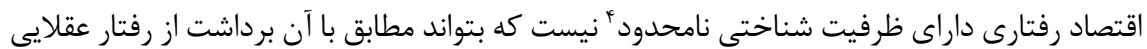

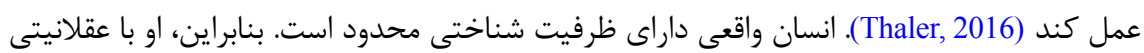
سازگًار با آن محدوديت ظرفيت شناختى در دنياى واقعى تصميم مى گيرد. در همين راستا، اقتصاد رفتارى مفهوم نئوكلاسيكى عقلانيت را يك مدل تجويزى (نورماتيوها) درباره رفتار عقلايى معرفى مى كند كه نمىتواند با واقعيتهاى تجربى داورى شود. در مقابل، اقتصاد

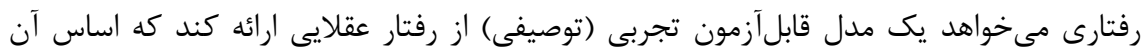

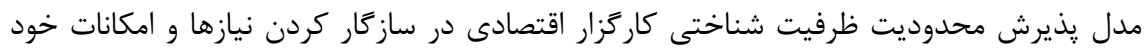
با محدوديتهاى موجود است. مدلى كه بتواند با آزمون تجربى مورد ارزيابى قرار گيرد و در صورت

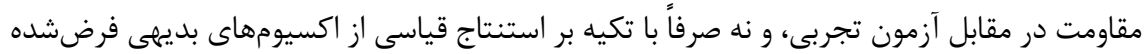
درباره رفتار عقلايى، مدلى واقعبينانه از رفتار عقلايى كاركزار اقتصادى ارائه كند (Thaler, 2015).

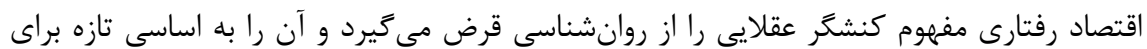

\section{Thaler}

2. Homo Economicus

3. Humans

4. Infinite Cognitive Capacity

5. Normative 
تعريف علم اقتصاد از رفتار عقلايى تبديل مى كند. در اين رويكرد روانشناختى به كنش عقلايى،

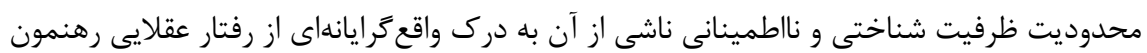
مىشود. در اين راستا، ايده يادگيرى از خطا مىتواند با محدوديت ظرفيت شناختى كارگزار اقتصادى

اقتصاددانان رفتارى متوجه شدهاند كه در نظركرفتن خطاى تصادفى به عنوان راهكارى براى مواجهه با جالشهاى ناشى از ظرفيت شناختى محدود كارگزار اقتصادى نمى تواند نشان دهد كه جرا انسان واقعى دجار خطاى سيستماتيك مىشود و توجه به اين نوع خطاست كه ما را با واقعيت كنش

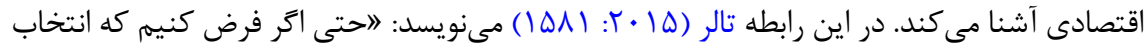

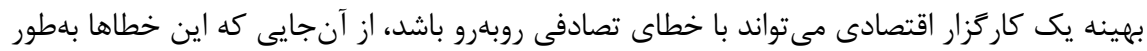
تصادفى توزيع شدهاند، متوسط آنها صفر خواهد بوده، بنابراين، بِيامدهاى رفتارهاى عقلايى (بهينه) كه خطاى تصادفى را در مدل رفتار عقلايى در نظر مى گيرد، در نهايت به جيزى متفاوت از ييشبينى

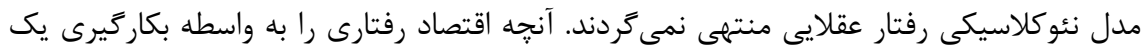
برداشت روانشناسانه از رفتارى عقلايى متمايز مى كند تاكيد بر امكان بروز خطاى سيستماتيك در اثر محدوديت ظرفيت شناختى كارگزار و ناطمينانى ناشى از يك جنين خطايى است.

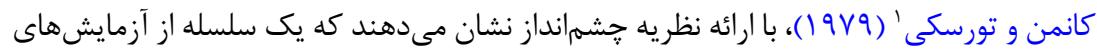
تجربى بيانكر آن است كه آنجه روانشناسان تحت عنوان قضاوت از آن ياد مى كنند و اقتصاددانان

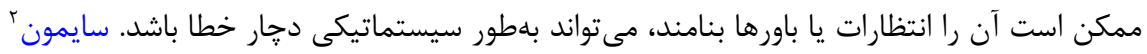
(919 ()، استدلال مىكند كه عقلانيت اقتصادى يك عقلانيت محتوايى است: ترجيح مطلوبيت بيشتر بر كمتر. اما عقلانيت در روانشناسى يك عقلانيت رويهاى "است. كاركزار عقلايى در اقتصاد

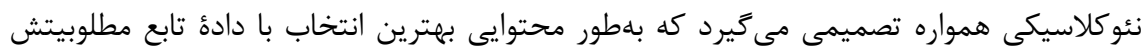
است. اما كارگزار عقلايى در روانشناسى تصميم خود را بهَّونهاى مى گيرد كه با توجه به دانش و ابزارهاى محاسباتي در دسترس بتواند يك تصميم معقول بهشمار آيد. بدين ترتيب، ظرفيت محدود شناختى كارگزار نقش اساسى در برداشت اقتصاد رفتارى درباره مفهوم رفتار عقلايى دارد.

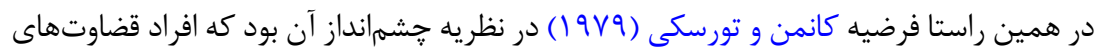

\section{Kahneman \& Tversky}


خود را اغلب با استفاده از برخى قواعد راهنما' انجام مى دهند. يك مثال، قاعدهُ راهنماى در دسترس

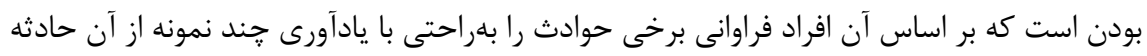

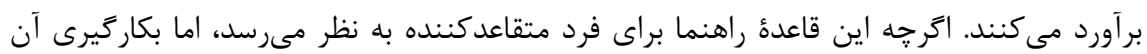
باعث ييشبينى همراه با خطاى سيستماتيك در مواردى مىشود كه فراوانى مذكور همكرا نگردد.

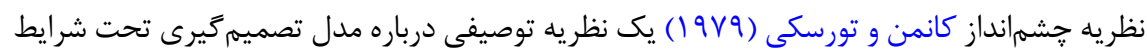

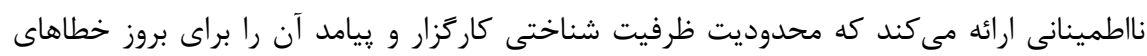

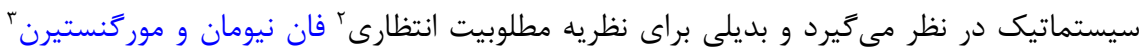

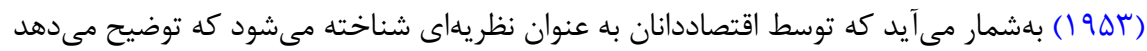

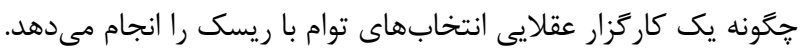
اقتصاد رفتارى به موضوع يادگيرى در رابطه با رفتار عقلايى توجه دارد. در اين رويكرد با استفاده

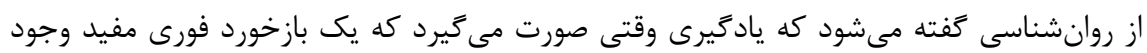
داشته باشد. اما يادكيرى حتى در يك محيط خيلى ساده هم مى تواند فرايند سختى باشد. با توجه

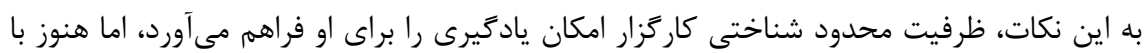
ادعايى كه كارگزار مىتواند نقاط بهينه حداكثركننده مطلوبيت يا سود را بدون خطا تشخيص دهد فاصله زيادى دارد. با توجه به ملاحظات فوق، نظريه جشمانداز كه نظريه انتخاب تحت شرايط محدوديت ظرفيت شناختى و ناطمينانى را مورد بازنكرى قرار ميدهد و در عمل جايخزينى براى مفهوم نئوكلاسيكى

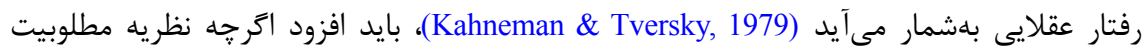

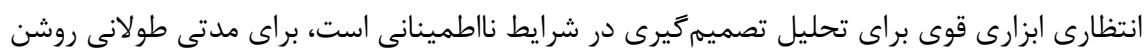

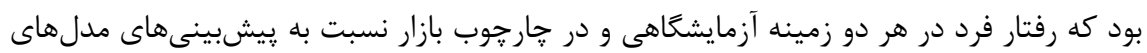

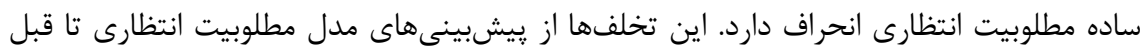

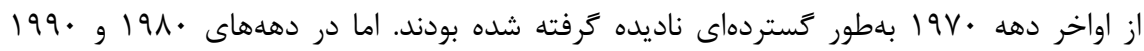

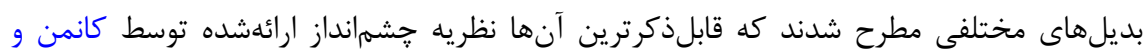

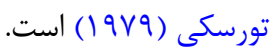

با توجه با مباحث يیشين درباره اقتصاد رفتارى و تاكيد آن بر محدوديتهاى شناختى كارگزار

1. Some Kind of Rule of Heuristic

2. Expected Utility (EU) Theory

3. Von Neumann \& Morgenstern 
اقتصادى، اكنون بهتر مىتوان رابطه بين مفهوم نئوكلاسيكى رفتار عقلايى و نظريه تعادل عمومى فيكى

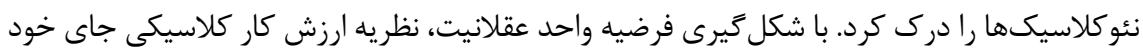

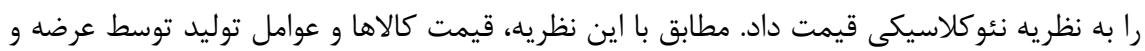

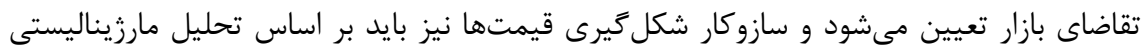
درباره نقاط بهينه مصرف و توليد توضيح داده شود (Granovetter, 2017).

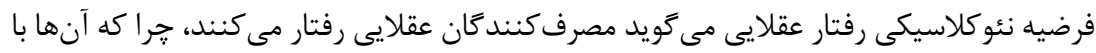

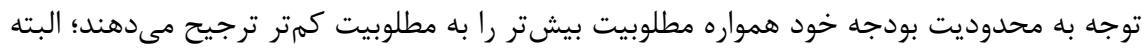

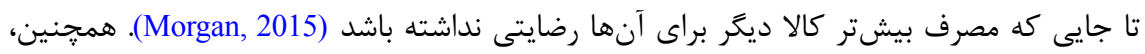

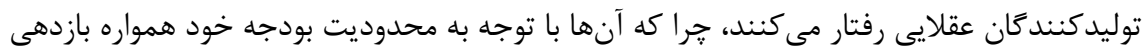

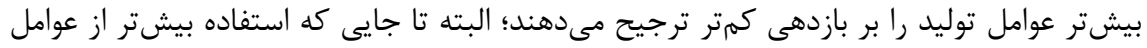

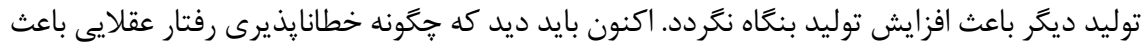

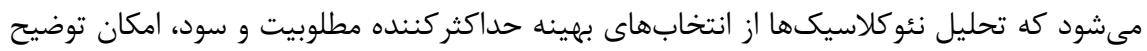

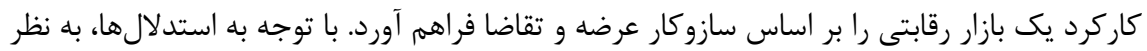

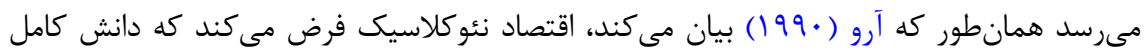

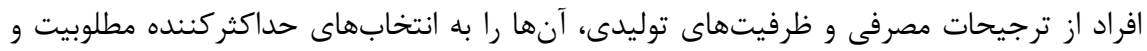

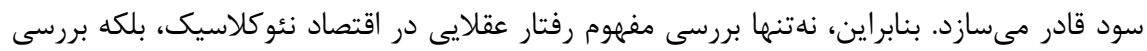

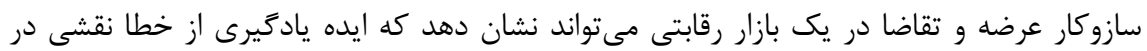

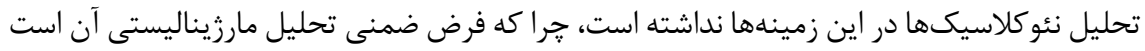

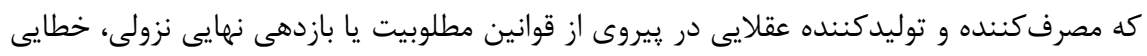

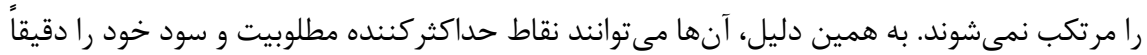

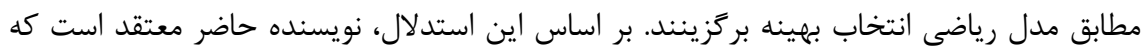

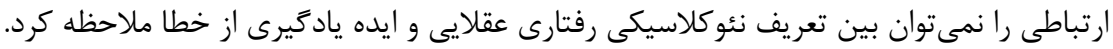

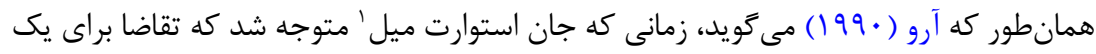

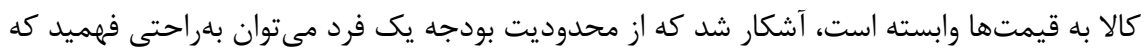

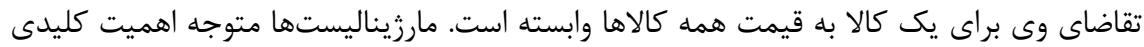
اين نكته براى كاربرد فرضيه عقلانيت خود به منظور توضيح نقش سازوكار بازار در ايجاد تعادل 
عمومى در اقتصاد شدند. اگر فرضيه عقلانيت نئوكلاسيكى به معناى آن است كه مصرفكننده و توليدكننده مطلوبيت و سود خود را با توجه به محدوديت بودجهشان بيشينه (حداكثر) مى كنند، محدوديتى كه خود تحت تاثير قيمتهاى تعادلى بازار' قرار دارد، يس قيمت تعادلى بازار از طريق

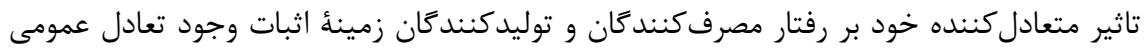

$$
\text { را در اقتصاد فراهم مى آورد. }
$$

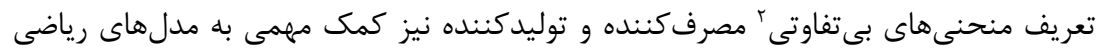

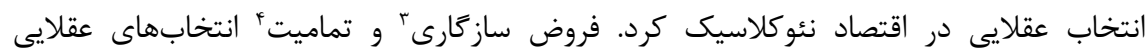
نشان مىدهد كه منحنىهاى بى تفاوتى مطلوبيت مصرفكننده (يا منحنىهاى بىتفاوتى امكانات

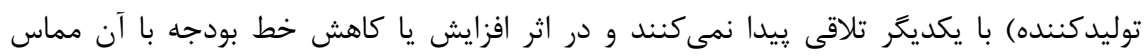
مىشوند. بنابراين، با استفاده از روش لاكرانزه مىتوان نقاط بيشينه كننده مطلوبيت يا سود را براى مصرفكننده و توليدكننده در جايى تعيين كرد كه منحنىهاى بىتفاوتى خطوط بودجه را قطع مى كنند.

از آنجايى كه نئو كلاسيكها فرض مى كنند كه ييروى يك مصرف كننده بيشينه كننده مطلوبيت

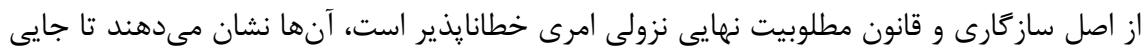

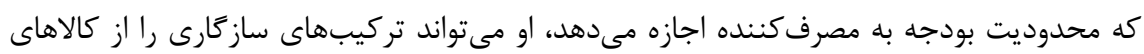

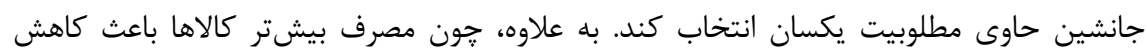
مطلوبيت آنها مىشود، كاهش قيمت آن كالاها در بازار باعث افزايش تقاضاى آنها تا جايى مى مئدون

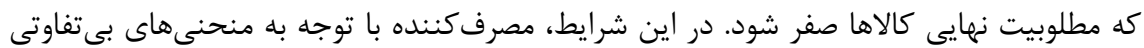

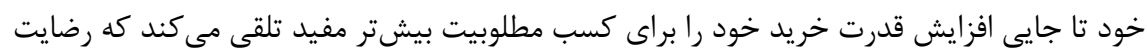

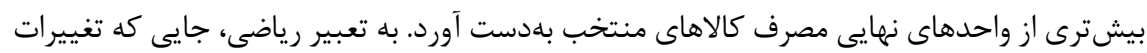
تابع مصرف مقيد به محدوديت بودجه صفر شود، نقطه اوج مصرف عقلايى خواهد بود. بدين ترتيب،

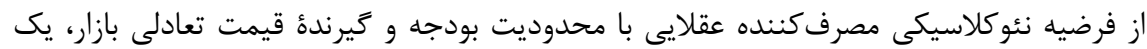

$$
\text { منحنى تقاضا با شيب نزولى استخراج مىشود. }
$$

نئوكلاسيكها استدلال مشابه البته با مضمون متفاوتى را در مورد نقاط بهينه عملكرد يك

1. Equilibrium Market Prices

2. Indifference Curves

3. Consistency

4. Completeness

5. Lagrange Method 
توليد كننده عقلايى بيشينه كننده سود و داراى محدوديت امكانات توليد و گيرنده قيمتهاى تعادلى

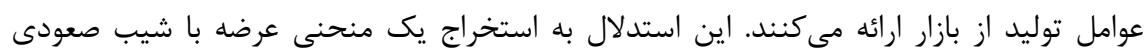
منتج مى گردد. به عقيده نويسنده حاضر، تفسير نئوكلاسيكى رفتارهاى عقلايى مصرفكننده و و توليد كننده و نقش آن رفتارها در شكل گيرى منحنى هاى تقاضا و عرضه و توضيح سازوكار بازار متكى

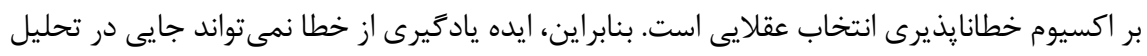

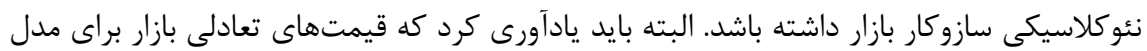

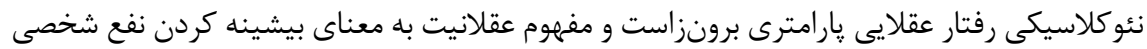

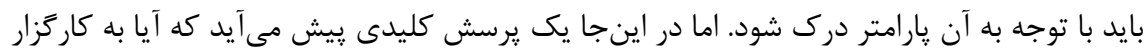

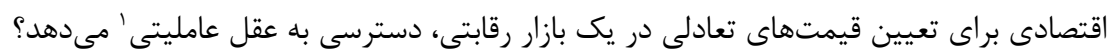
اقتصاد نئوكلاسيكى رفتار عقلايى منعكس در منحنىهاى عرضه و تقاضا را مبناى تحليلى از

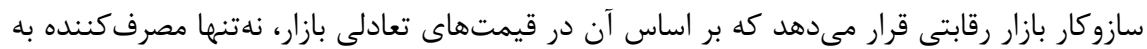

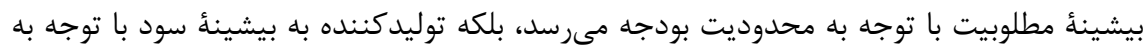
محدوديت امكانات توليد مىرسد. بدين ترتيب، سازوكار بازار به ياسخى مناسب براى مسئله اقتصادى

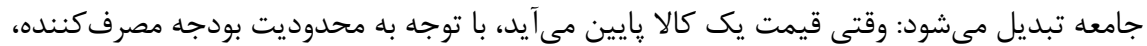

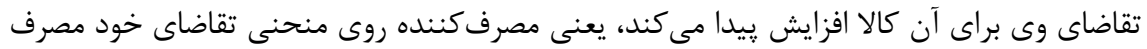

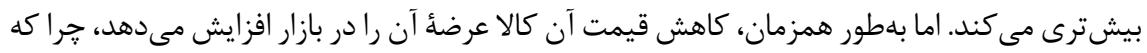
توليدكننده افزايش سود خود را در تامين تقاضاى اضافى از طريق افزايش توليد با توجه به بودجهاش مىبيند. در اين شرايط، توليدكننده با بهرهبردارى بيشتر از عوامل توليد ميزان توليد محصول به بازار را روى منحنى عرضه خود افزايش مى دهد. بر اساس واكنشهاى عقلايى مصرف كننده و توليدكننده،

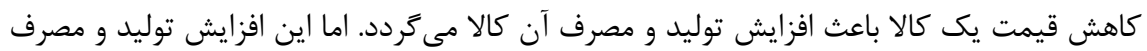

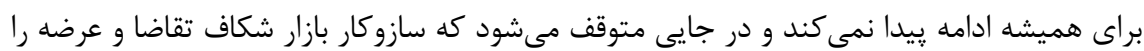

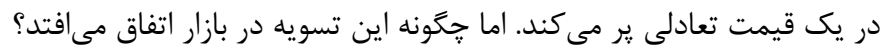

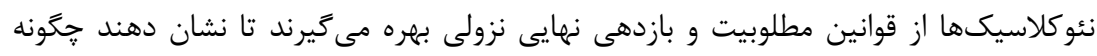
تسويه بازار رقابتى به سوى يك تعادل عمومى اتفاق مىافتد: هنگَامى كه قيمت يك كالا كاهش ييدا مى كند، مصرفكننده عقلايى فقط تا جايى تقاضاى خود از آن كالا را افزايش مىدهد كه مصرف بيشتر كالا هنوز برايش رضايت داشته باشد. بنابراين، حركت او روى منحنى تقاضا تا جايى ادامه 
مىيابد كه مطلوبيت اضافى ناشى از مصرف كالا با توجه به قيد بودجه صفر شود. در سوى مقابل، با كاهش قيمت آن كالا، توليدكننده عقلايى فقط تا جايى حاضر به استفاده بيشتر إنى از عوامل توليد خود براى تامين تقاضاى اضافى است كه بهرهورى نهايى عوامل توليد وى صفر شود. بنابراين، اين تحليل نئوكلاسيكى از تغييرات مارزينال مطلوبيت مصرفكننده و بهرهورى عوامل توليد است كه سازوكار بازار رقابتى را قادر به تسويه بازار يعنى ير كردن شكاف تقاضا و عرضه براى يكى يك كالا مى كند. دقيقاً جايى فرايند تسويه بازار به نتيجه مىرسد كه ارزش ذهنى يك كالا با بهرهورى (كارايى فنى) عوامل

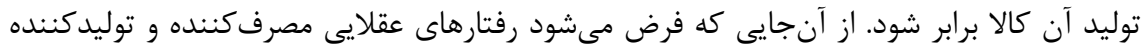
مصون از هر گونه خطايى هستند، يك جنان مصونيتى از خطاست كه تحليل نئوكلاسيكى سازوكار

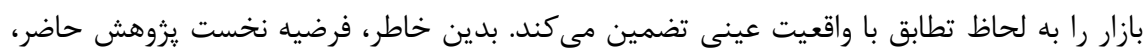
مبنى بر اينكه خطانايذيرى رفتار عقلايى مقدمة استدلال رياضى نئوكلاسيكها درباره كاركرد سازوكار بازار رقابتى است، تاييد مىشود.

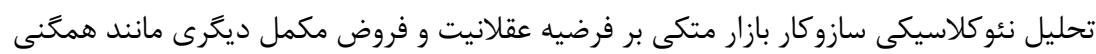
كالاها و عوامل توليد است. مازاد تقاضا يا عرضه كالاها به واسطه واكنشهاى عقدئ علايى كاركزاران اقتصادى تسويه مىشود. اما دقيقاً در جه نقطهاى؟ جايى كه ارزش ذهنى يك كارِ كالا با كارايى فنى عوامل توليد برابر مىشوند. در اين نقطه، مصرفكننده انگيزهاى براى مصرف بيشتر و بنگاه انگَيزهاى

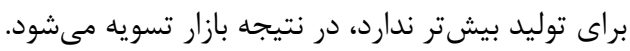

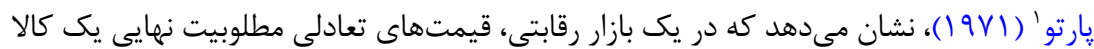
را با بهرهورى نهايى عوامل توليد برابر مىكنند و بدين ترتيب، مسئله تخصيص بهينه عوامل توليد كمياب به ترجيحات ذهنى به بهترين وجه ممكن حل مى

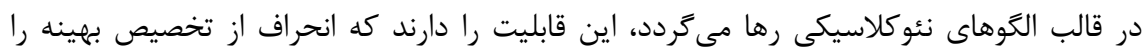
تبيين كنند (Radner, 1982; Hart, 1975). وقتى از سطح فرد به سطح همه كارگزاران مىرويم، نئوكلاسيكها براى آن كه بتوانند نقش سازوكار بازار را در رسيدن به تعادل عمومى توضيح دهند، بايد

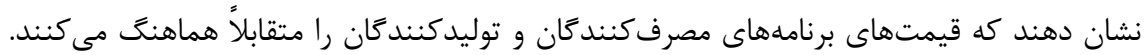

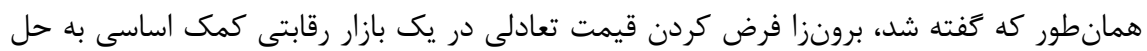
مسئله مذكور مى كند. وقتى مصرفكنندگان يا توليدكنندكان از قيمتهاى تعادلى بازار براى تعيين خطوط بودجه و مصرف و توليد بهينه خود استفاده مى كنند، آنها ناخواسته عاملى متعادل كننده 
را وارد تصميمات خود مى كنند كه مىتواند برنامههاى جداگانه آنها را بهطور متقابل سازگًار كند.

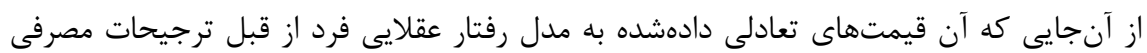
و امكانات توليدى را در بازار به عنوان يك كل برابر ساخته است، تصميماتى كه از يكسو، خود به لحاظ فردى بهينه و عارى از هر خطايى است، و از سوى ديگر، بر اساس آن قيمتهاى متعادل كننده

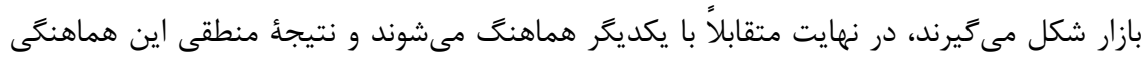

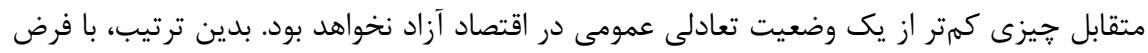

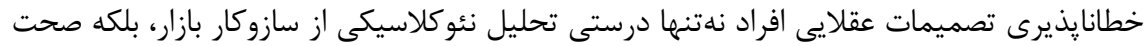
تحليل نئوكلاسيكى درباره وجود يك وضعيت تعادل عمومى در اقتصاد تضمين شده است.

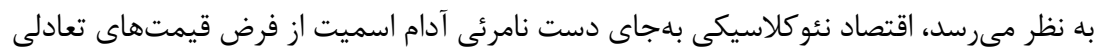
برونزا استفاده مى كند تا به لحاظ رياضى اثبات كند كه مسئله بسيار رييجيده هماهنكَى متقابل و همزمان رفتارهاى عقلايى كار گزاران متعدد در يك اقتصاد از طريق سازوكار قيمتها قابل حل است. والراس' (9 \& (1)، نخستين كسى است كه يك مدل رياضى براى اثبات وجود يك تعادل عمومى در اقتصاد رقابتى ارائه مى كند. او نشان مى دهد كه تحت شرايط معينى رفتار بيشينه كننده توليدكنندكان و مصرفكنندكان به تعادل ميان مقادير معينى از عرضه و تقاضا براى هر محصول و هر بازار عوامل توليد مى انجامد.

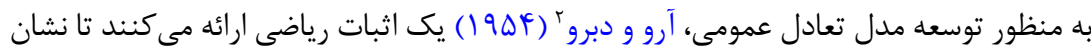
دهند وجود يك تعادل عمومى در اقتصاد بازار ناشى از يك فرايند تعديل يوياست. قيمتها به عنوان سيخَنالهايى از يك تابع مازاد تقاضا تغيير مى كنند، در حالى كه تقاضاهاى اضافى در بازگشت مطابق

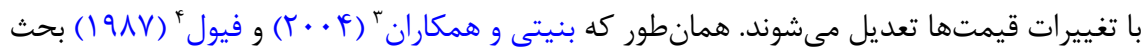

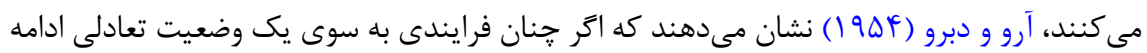

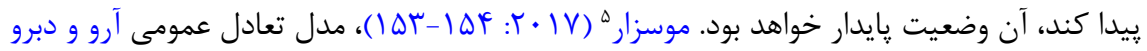

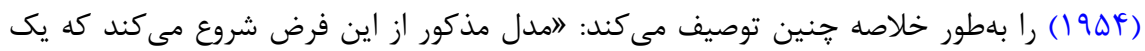

1. Walras

2. Arrow \& Debreu

3. Benetti et al. 
تعادل رقابتى' بايد يكى بهينه يارتوَّ باشد و همه بهينههاى يارتو نيز بايد بالقوه تعادل هاى رقابتى

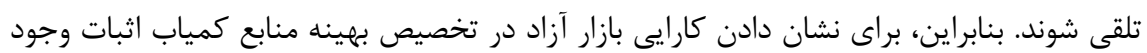

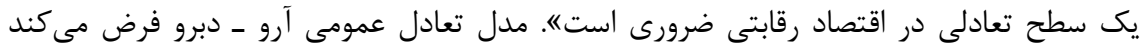
كه هر مصرفكنندهاى يك انتخاب مصرفى مقيدشده به بودجهاش و يك مجموعه از يرداختهاى

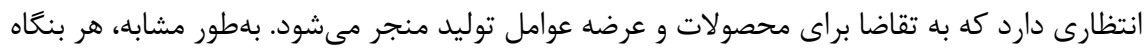

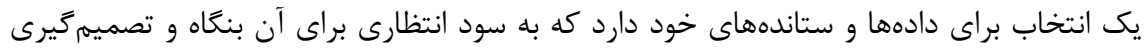

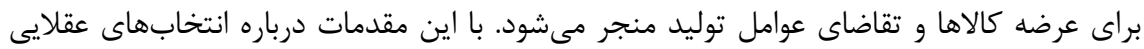

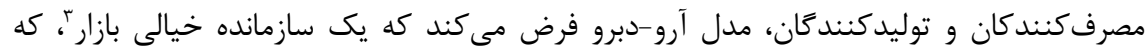

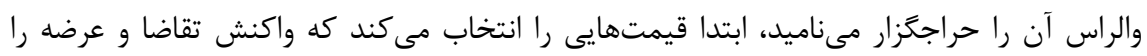
در بازار به يكديكر امكانيذير مىسازد. واكنش بعدى به قيمتها توسط همان سازمانده خيالى بازار

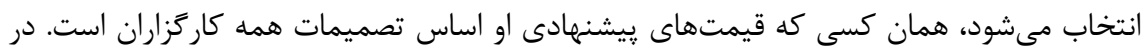

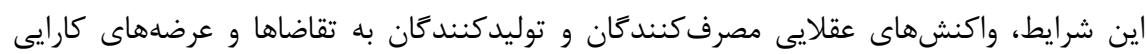
منتهى مىشوند. سيس سازمانده خيالى تقاضاها و عرضهها را با هم مقايسه مى كند و متناسب با بـ آنها قيمتها را مجدداً تعديل مىنمايد، بهَّونهاى كه قيمتهاى جديد باعث تسويه بازار يا حذف مازاد از آنجايى كه اين فرايند در نهايت به ارائه كالاها و عوامل توليدى مى انجامدل كهد در قيمتهاى يِيشنهادى آن سازمانده خيالى تقاضا يا عرضه شده است، قيمت نهايى كه بتواند آن عرضهها و تقاضاها را برابر كند، يك قيمت تعادلى خواهد بود. آرو و دبرو (9DF (1) مى كويند اين قيمت تعادلى بهينه يارتو نيز هست، جرا كه در آن قيمت ارزش ذهنى يك كالا با بهرهورى (كارايى فنى) عوامل توليد

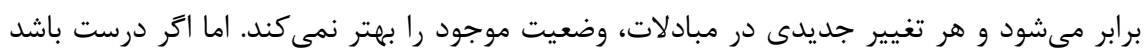
كه فرض كنيم سازمانده بازار موجودى خيالى است، آيا درست نيست كه بهطور مشابه فرض كنيم

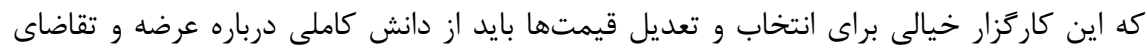
همه مشاركت كنند

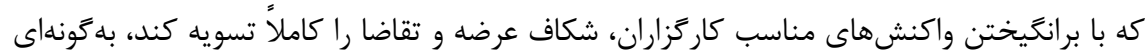

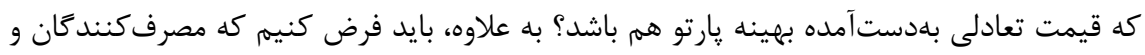

1. Competitive Equilibrium

2. Pareto-Efficient

3. A Fictive Market-Organizer 
توليدكنند ان نيز يِيامهاى آن سازمانده خيالى را بدون هيج خطايى دريافت مى كنند و واكنش كاملاً

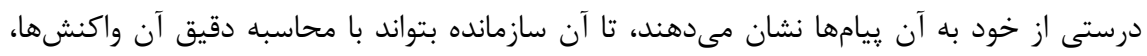

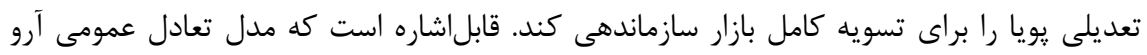

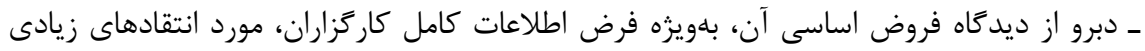

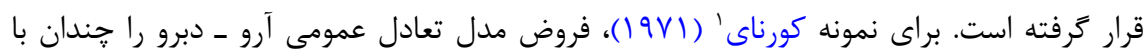
واقعيتهاى اقتصادى ساز كار نمىبيند.

\section{فرضيه انتظارات عقلايى و ارتباط آن با مفهوم رفتار عقلايى}

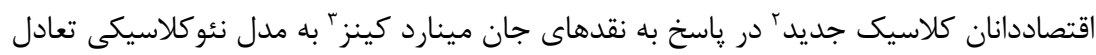

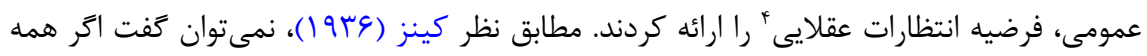

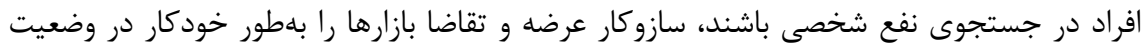

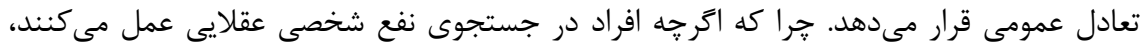

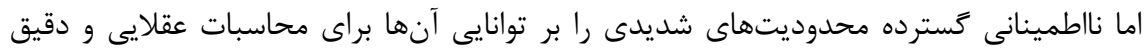

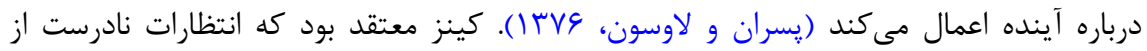

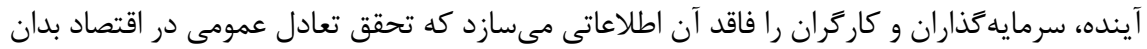

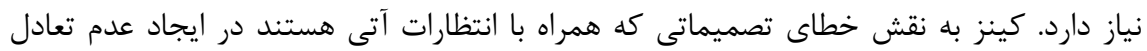

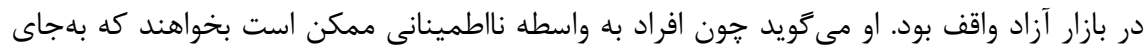

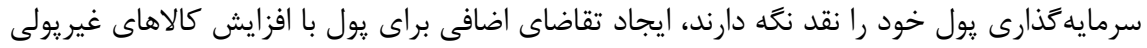

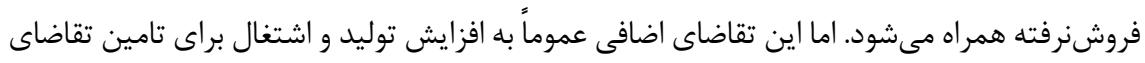

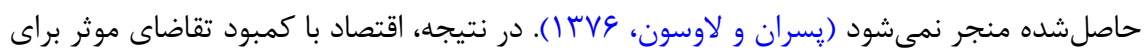

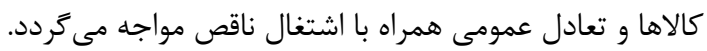

\section{فرضيه انتظارات عقلايى و ارتباط آن با مفهوم نئوكلاسيكى رفتار عقلايى}

با توجه مقدمات فوق، در اين بخش نقش فرضيه انتظارات عقلايى در رابطه با مفهوم نئو كلاسيكى

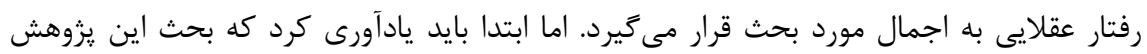

\section{Kornai}

2. New Classical Economists 
در رابطه با فرضيه انتظارات عقلايى بر اين يرسش متمركز مىشود كه آيا فرضيه انتظارات عقلايى

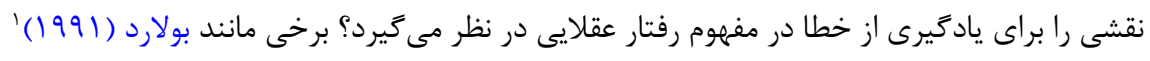

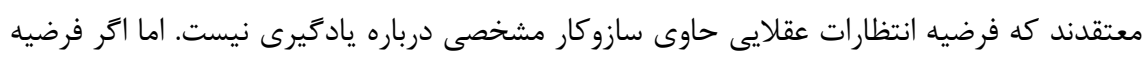

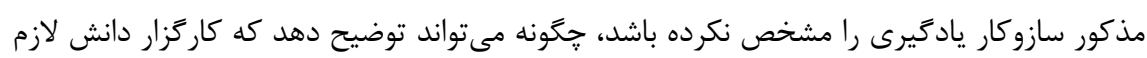

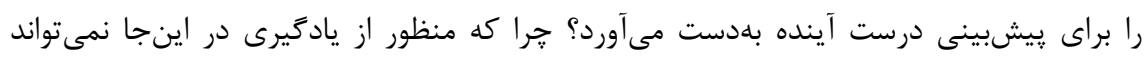
جيزى جز كسب همان دانش باشد. بنابراين، به نظر مىرسد مراجعه به تحليل نظريه يُ بردازان انتظارات

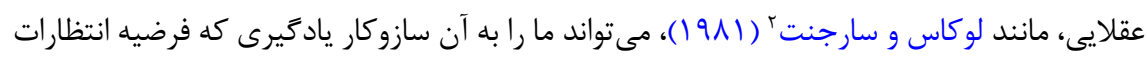
عقلايى را در بر دارد و ييامدهاى آن براى توسعه مفهوم رفتار عقلايى بهويزه از نظر ارتباط آن با ايده يادكيرى از خطا ضرورى است، راهنمايى كند.

\section{انتظارات عقلايى و مسئله استفاده عقلايى از اطلاعات}

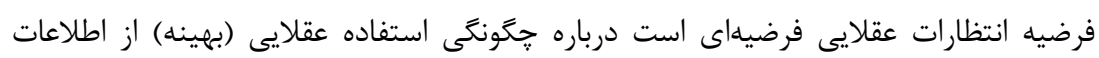
موجود براى شكلدهى به انتظارات آتى. اخر به مفهوم رفتار عقلايى در اقتصاد نئوكلاسيكى توجه

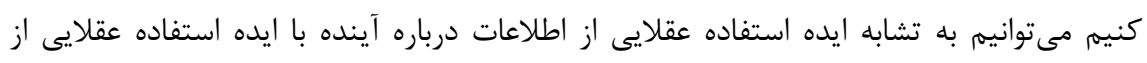

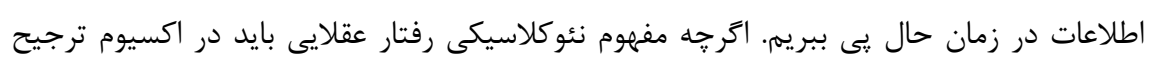

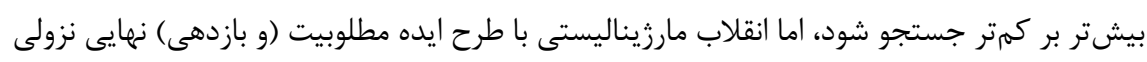

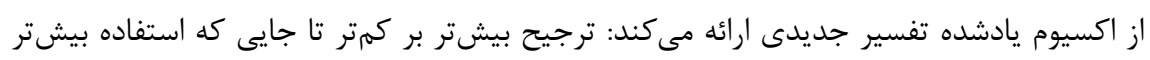

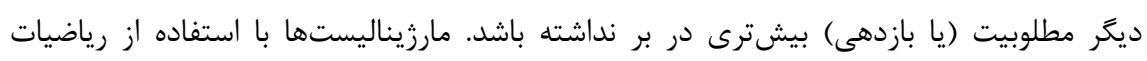

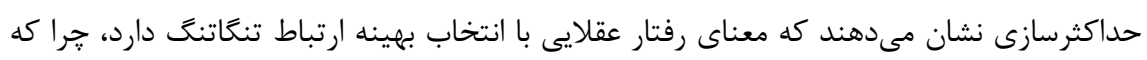
انتخاب بهينه انتخابى است كه مطلوبيت يا سود را با توجه به امكانات موجود حداكثر مي كنداند

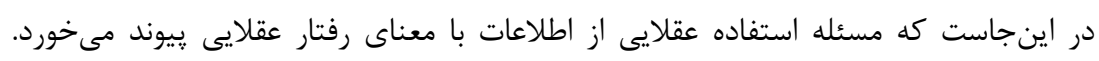

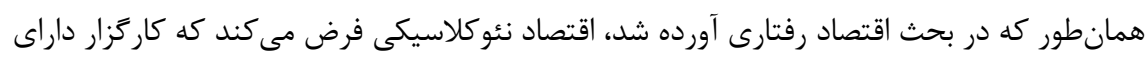
ظرفيت شناختى نامحدودى است كه مىتواند بدون خطا نقاط بهينه مصرف و توليد (ترجيح بيشتر

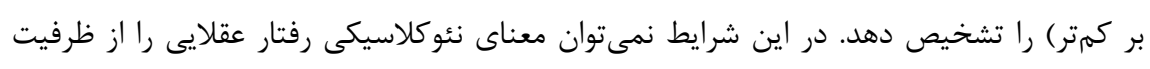

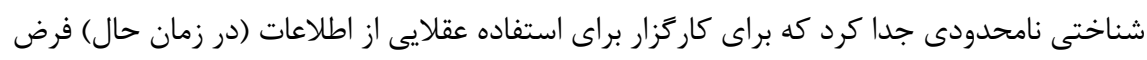
مى كند كه بتواند هدف ترجيح بيشتر بر كمتر را در عمل محقق سازد. فرضيه انتظارات عقلايى اين

1. Bullard

2. Lucas \& Sargent 
ظرفيت نامحدود شناختى را به زمان آينده تسرى مى دهد. البته آن فرضيه مى يذيرد كه همانطور كه

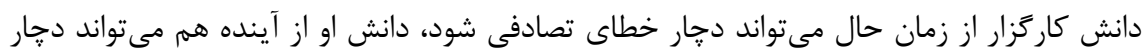
خطاى تصادفى گردد. اما همانطور كه نقد اقتصاد رفتارى بر معناى نئوكلاسيكى رفتار عقلايى نشان مى دهد، نمىتواند در خارجوب مفهوم نئو كلاسيكى رفتار عقلايى خطاى سيستماتيكى را در انتخاب عقلايى كاركزار تصور كرد. فرضيه انتظارات عقلايى عدم بروز خطاى سيستماتيك را در در استفاده عقلايى از اطلاعات موجود از زمان حال به آينده تسرى مى دهد. در اين رابطه است كه مىتوان ديد جَكَونه فرضيه انتظارات عقلايى به نئو كلاسيكها كمك مى كند تا نشان دهند جَكونه انتظارات از آينده نمى تواند مانعى براى تحقق تعادل عمومى در اقتصاد باشد، جايى كه كارگزاران از اطلاعات موجود براى ييشبينى آينده استفاده عقلايى مى كنند.

استفاده عقلايى از اطلاعات و كمينه كردن خطاى تصادفى در فرضيه انتظارات عقلايى با توجه مباحث يادشده، فرضيه انتظارات عقلايى بدان معناست كه شكل عقلايى است. عقلايى بودن در اينجا به معناى استفاده بهينه از اطلاعات براى تصميمَّيرى صحيح است. انتظارات عقلايى هستند جرا كه از اطلاعات موجود براى پِيشبينى آينده استفاده بهينه مى كنند. بنابراين، فرضيه انتظارات عقلايى بر קيشفرض بهينه بودن رفتار عقلايى' يعنى استفاده

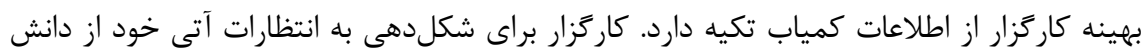
موجود بهترين استفاده را مى كند. با توجه به مباحث كذشته، بهينه بودن رفتار عقلايى يعنى استفاده عقلايى از اطلاعات براى ترجيح بيشتر بر كمتر با سازوكار يادگيرى در فرضيه انتظارات عقلايى، كه با كمينه (حداقل) كردن خطاى تصادفى در ريشبينى آينده ارتباط نزديكى ييدا مي كند. كاركزار

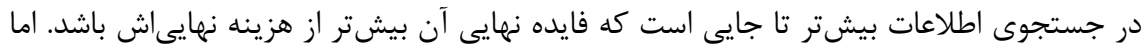
بدين منظور بايد خطاى تصادفى اين جستجو را كمينه كند. به عبارت ديگر، او نبايد در تشخيص نقاط بهينه جستجوى اطلاعات (استفاده عقلايى از اطلاعات موجود) دجار خطاى سيستماتيكى شود. منظور از يادكيرى از خطا، به مثابه يك سازوكار يادكيرى براى تشكيل انتظارات عقلايى آن است

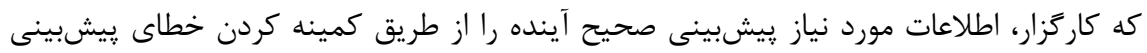
خود بهدست آورد، به گونهاى كه دجار خطاى سيستماتيكى نشود. در همين راستا، همانطور كه 
اوانز و هانكافوشى' ( ( . - ז: ه) بيان مى كنند: لانتظارات عقلايى به مثابه انتظاراتى تعريف مىشوند كه به لحاظ رياضى مشروط به همه اطلاعات در دسترس كارگزار هستنده. در اينجا منظور از يادكيرى، بهينهسازى استفاده از اطلاعات با توجه محدوديتهاى موجود است. كارگزار با ياد كيرى از كمينه كردن خطاى خود از بروز يك خطاى سيستماتيك در يِيشبينىها جلوكيرى مى كند. فرض اساسى فرضيه انتظارات عقلايى آن است كه كار گزار، مانند يك اقتصادسنج، از مدلهاى آمارى براى يِيشبينى خود استفاده مى كند. جون اين مدلها بر اساس مفهوم تصادفى خطا شكل گرفتهاند،

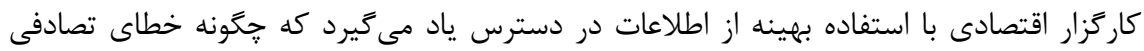
انتظارات عقلايى خود از آينده را كمينه كند. براى نشان دادن آنكه فرضيه انتظارات عقلايى با معرفى سازوكار يادكيرى از كمينه كردن

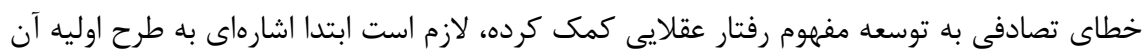

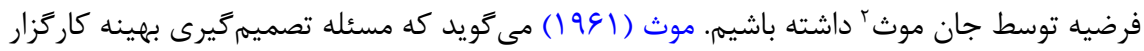

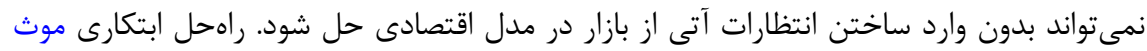

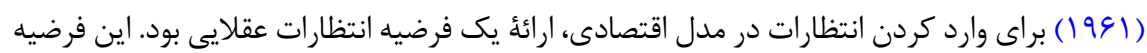

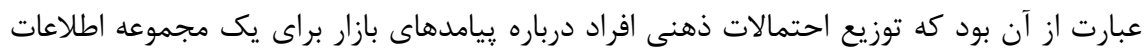

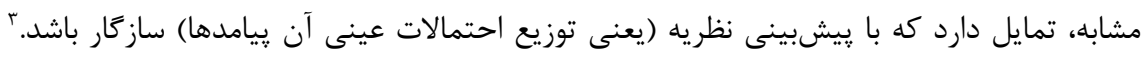

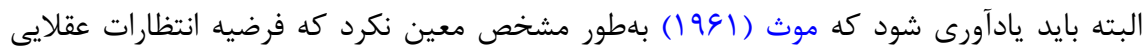

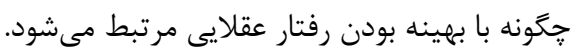

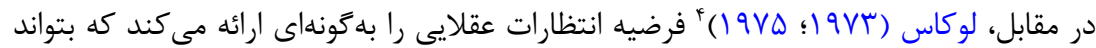

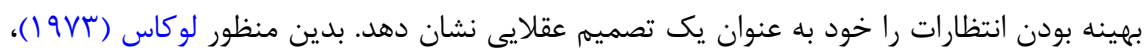

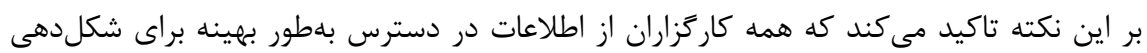
به انتظارات خود استفاده مى كنند. معناى پيشبينى بهينه در اينجا همان پيشبينى حداقل خطاى

\section{Evans \& Honkapohja}

2. John Muth (1930-2005)

r. در حار קوب مفهومى موث ( (991)، انتظار ذهنى كاركزاران اقتصادى برابر است با انتظار رياضى شرطى متغير

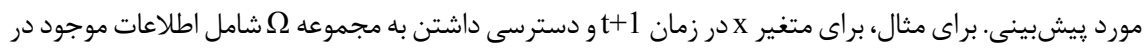

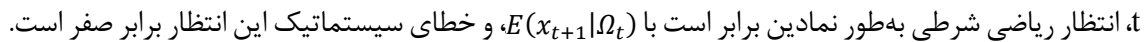
$E\left(x_{t+1}-x_{t+1}^{e}\right)=E\left[x_{t+1}-E\left(x_{t+1} \mid \Omega_{\mathrm{t}}\right)\right]=E\left[\left(x_{t+1}\right)-E\left(x_{t+1} \mid \Omega_{\mathrm{t}}\right)\right]=E\left(x_{t+1}\right)-E\left[E\left(x_{t+1} \mid \Omega_{\mathrm{t}}\right)\right]=0$ 4. Lucas 
مربعات مشروط به اطلاعات در دسترس كارگزار است. بدين ترتيب، لوكاس (س (1) روش حداقل مربعات را براى يادگيرى از خطا تصادفى به عنوان معيارى براى تعريف انتظارات بهينه يیشنهاد مى كند. فرضيه انتظارات عقلايى لوكاس ييشنهاد مىكند كه كارگزار اقتصادى بر اساس توزيع احتمالى تعادلى' دادهشده و اطلاعات در دسترس خود، خطاى تصادفى انتظارات از آينده را كمينه مى كند. در واقع، روش كمينه كردن خطا خود سازوكارى براى بهينه كردن مشروط انتظارات از آينده

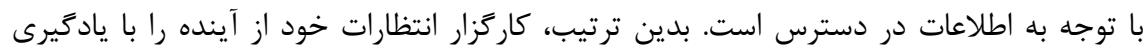

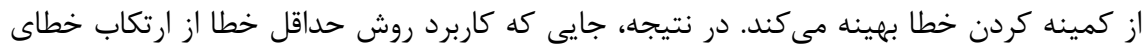
سيستماتيكى توسط كاركزار در ييشبينى آينده جلوكيرى مى كند، لوكاس از فرضيه انتظارات عقلايى

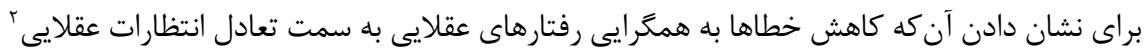

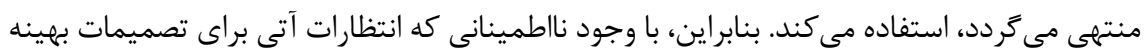

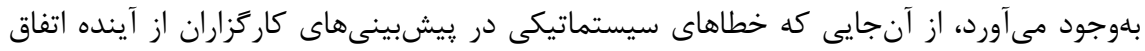
نمىافتند، تعادل انتظارات عقلايى بيانكر تخصيص بهينه منابع كمياب به نيازهاى متنوع افراد است.

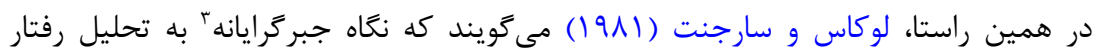
كارگزار اقتصادى بايد جاى خود را به نگًاهى آمارى دهد تا بتوان تصادفى بودن رفتار فردّ را در مدل

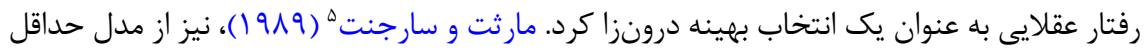
مربعات يادگيرى براى توضيح سازوكار شكل گيرى انتظارات افراد استفاده مى كنيند. بولارد (199(1)، معتقد است اتر جه وقتى بخواهيم از تكنيكهاى اقتصادسنجى براى حلى مل مسئله استنتاج فردى در يیشبينى آينده استفاده كنيه، ركرسيون حداقل مربعات نقطه شروع خوبى است،

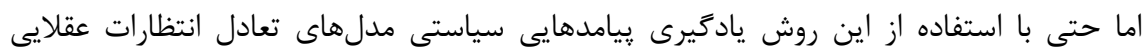

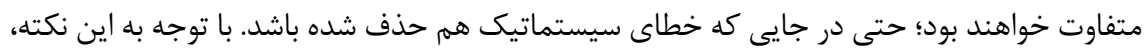
بسيارى از مدلهاى انتظارات عقلايى با تعادلهاى جند مارثت و سارجنت (91919) مبنى بر نقش همكر ايى يادگيرىها به واسطه كاهش خطاهاى تصادفى در

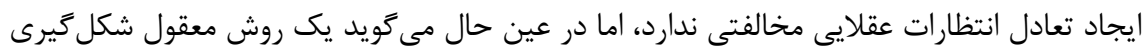
انتظارات همواره باعث همكرايى به سوى تعادل انتظارات عقلايى نمى عرددد.

1. The Equilibrium Probability Distribution

2. Rational Expectation Equilibrium

3. Deterministic

4. Randomness of Individual's Behavior

5. Marcet \& Sargent 
همان طور كه اوانز و هانكافوشى ( ( • + اشاره مى كنند، تحولات اخير در مدل هاى انتظارات فراتر از انتظارات عقلايى رفته و توجه خاصى به سازوكارهاى يادَيرى داشته است. آنها نشان مى دهند كه مواردى وجود دارند كه فرايند يادگيرى به سمت يكى تعادل انتظارات عقلايى همخرا نمىشود و و

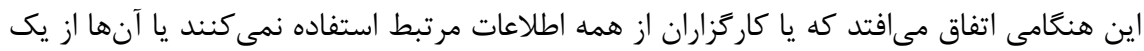
قاعده يادگيرى استفاده مى كنند كه به همكر ايى كامل منتهى نمى گتردد. در همين رابطه بايد اشاره كرد كه آرو (919 (1) در نقد خود بر فرضيه انتظارات عقلايى مي گويد، هزينه دستيابى به اطلاعات گَسترده از شرايط بازار، كه بسيار مورد تاكيد طرفداران سيستم قيمتها در مقابل برنامهريزى متمركز

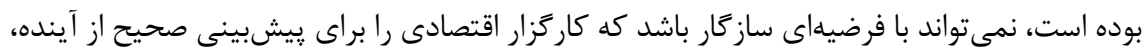

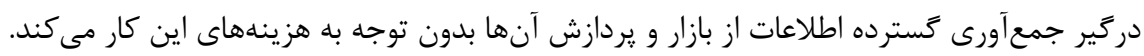

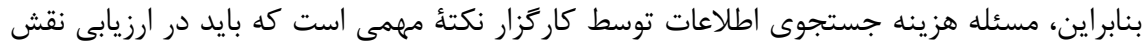
فرضيه انتظارات عقلايى در توسعه مفهوم رفتار عقلايى در نظركرفته شود. در عين حال، با درونزا

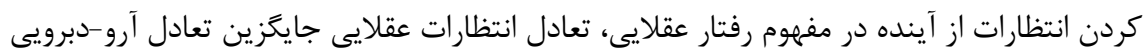

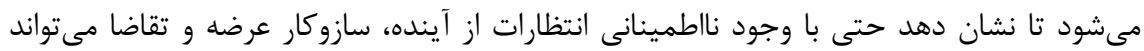
كماكان بازارهاى رقابتى را به سوى تعادل عمومى سوق دهد. اما آيا مىتوان خطاى انسانى ناشى از

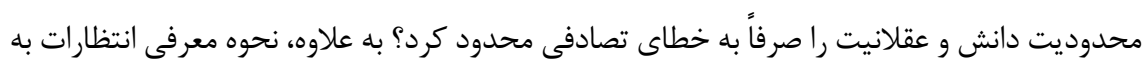

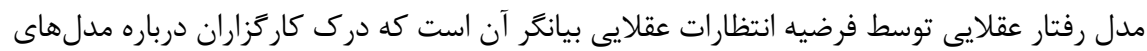

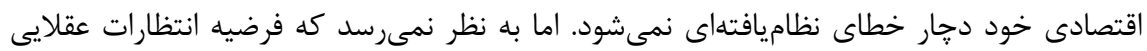
همه جالشهايى را كه خطاهاى انسانى، فراتر از خطاى تصادفى، براى تحليل رفتار عقلايى بلهوجود

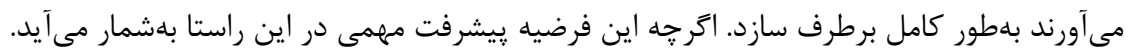

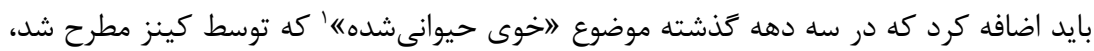
در قالب الكوهاى تعادل عمومى يويا با انتظارات عقلايى براى توضيح گديده اثر تغيير در ذهنيت و انتظارات (و نه بر اساس متغيرهاى بنيادين) بر فرايند فعاليتهاى اقتصادى و مسير تعادلى و امكان

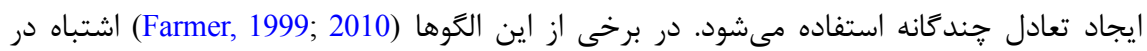

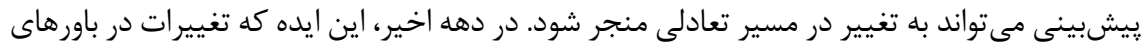

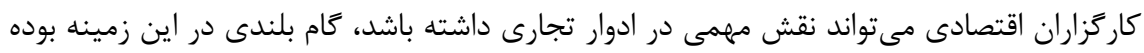

1. خوى حيوانىشده اشاره به نقش احساسات در تصميمكيرىهاى اقتصادى دارد. در حالى كه رفتارهاى

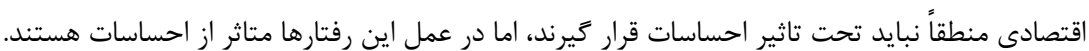


است. اكنون كه بحث ييرامون رفتار عقلايى در اقتصاد نئوكلاسيكى و ارتباط آن فرضيه انتظارات عقلايى به پايان رسيده است، نوبت بدان مىرسد كه به مفهوم رفتار عقلايى در ديد

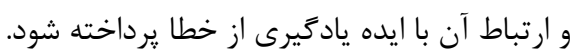

مكتب اتريشى: عقلانيت، يادكيرى از خطا، و فرايند بازار

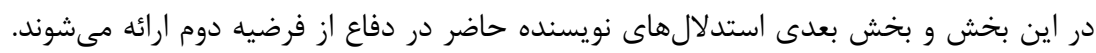

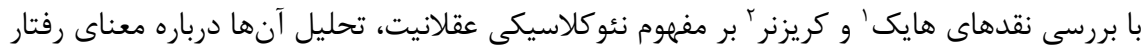

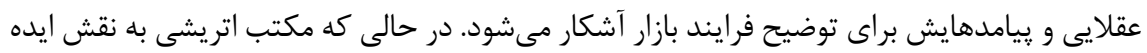

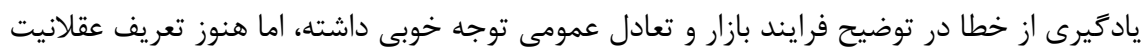

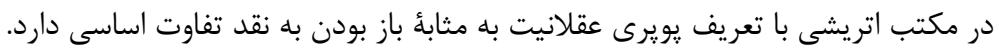

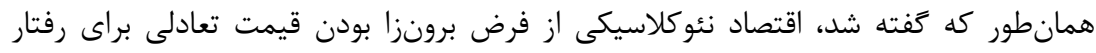
عقلايى، براى نشان دادن هماهنگ شدن متقابل تصميمات فردى از طريق سازوكار بازار استفاده مى كند. اما آن فرض باعث مىشود كه تحليل نئوكلاسيكى درباره نقش رفتار عقلايى در ايجاد تعادل

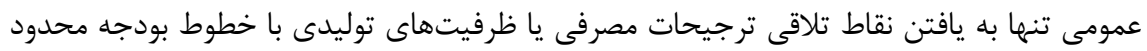

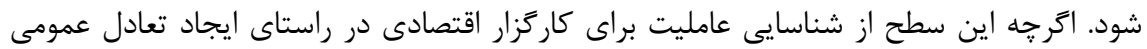
در اقتصاد اهميت كمى ندارد، اما فرضيه نئوكلاسيكى عقلانيت جيزى در دورين مورد اين كه آيا در يكى

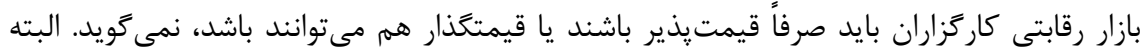

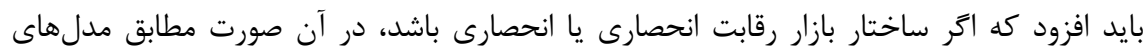
نئو كلاسيكى كاركزاران قيمتخذار خواهند بود، در حالى كه انتظارات هم مى بوانند عقلايى باشند.

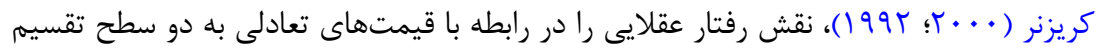

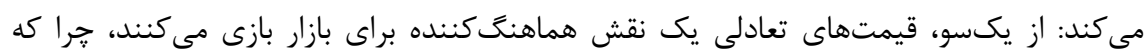
مصرف كنندًان و توليدكنندكان آن قيمتها را به عنوان قيمتهايى در نظر مى گيرند كه در دورههاى

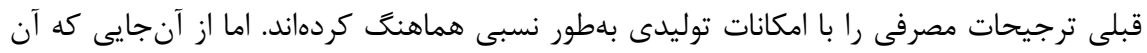
قيمتهاى تعادلى نمىتوانند بدون هيج خطايى عرضه و تقاضا را برابر كرده باشند، همواره اين امكان

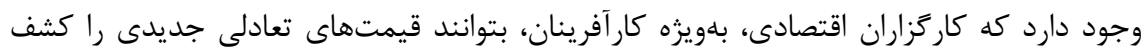

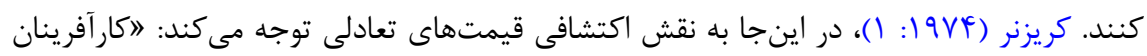


قيمت هاى جديدى راكشف مى كنند كه ترجيحات مصرفى و امكانات توليدى را در مقايسه با قيمتهاى قبلى بهتر هماهنگ مى كننده" كريزنر كشف قيمتهاى تعادلى جديد را محصول فعاليت كار آفرينان در يك فضاى رقابتى مىداند. كارآفرينان با كشف فرصتهاى سودآور باعث شكل تريرى قيمتهاى تعادلى جديدى مىشوند كه هماهنكى بيشترى را بين عرضه و تقاضا در بازار بلوجود مى آورند. نقد مكتب اتريشى بر مفهوم نئوكلاسيكى عقلانيت آن است كه انتخابهاى عقلايى كارگزاران را نمى توان

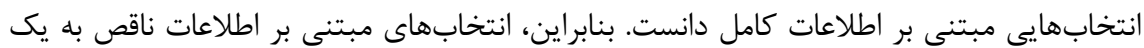

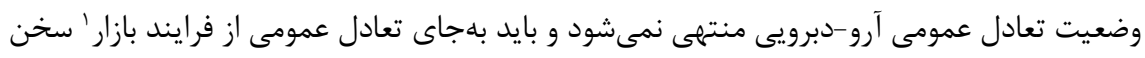

كفت (Coyne \& Boettke, 2020).

هايك (1) (1)، بيان مى كند كه اگر كاركزاران از اطلاعات كامل و عقلانيت خطانايذيرى برخوردار بودند، وقتى تعادل عمومى به عنوان يك وضعيت پايدار در اقتصاد برقرار شد، ديخر بهجز شوكهاى

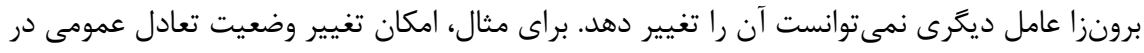

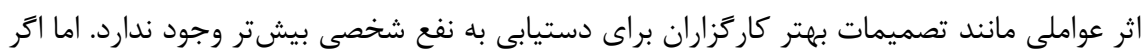

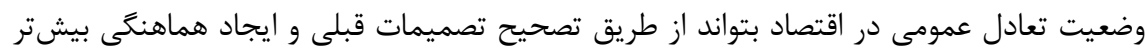
بين عرضه و تقاضا تغيير كند، ديگر نمىتوان رفتار عقلايى و تعادل عمومى را آنطور صورتبندى كرد

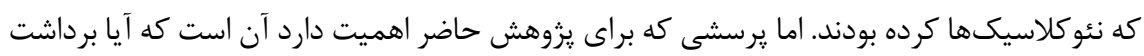

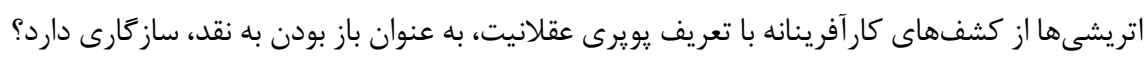

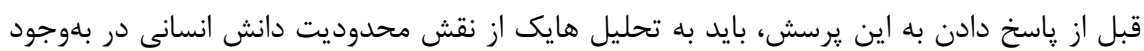
آمدن نظم خودجوش بازار آزاد و اهميت اساسى آن براى حل مسئله اقتصادى جامعه نتخاهى داشته باشيه.

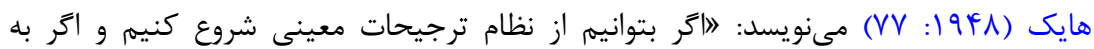
منابع كمياب شناخت كامل يِدا كرده باشيه، مشكلى كه براى حل مسئله اقتصادى جامعه مىماند

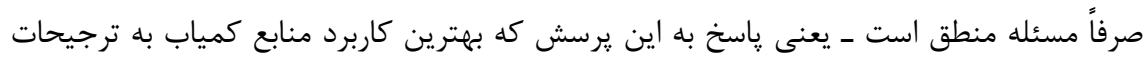

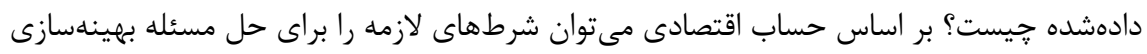

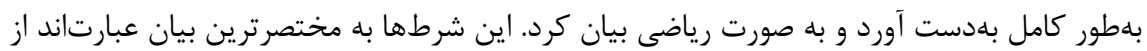
اين كه نرخهاى نهايى جانشينى بين دو كالا يا دو عامل بايد در تمام كاربردهاى مختلف آنها يكسان

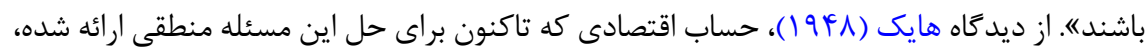




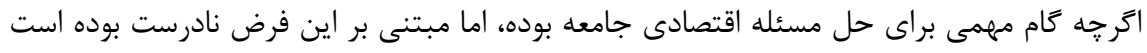

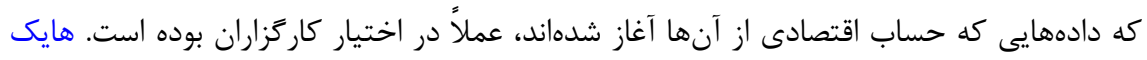

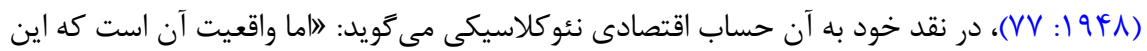

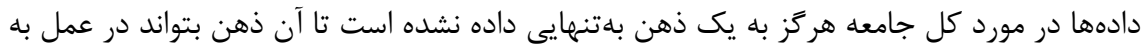

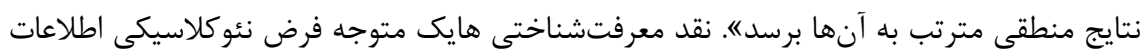
كامل كار كزار است. برخلاف نئوكلاسيكها، هايك مسئله اقتصادى جامعه را بر اساس ايده تقسيم دانش' تعريف

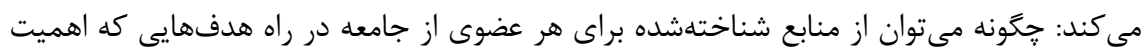

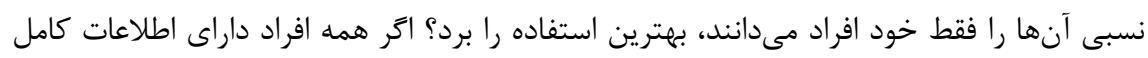

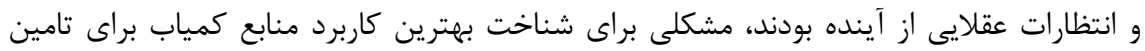

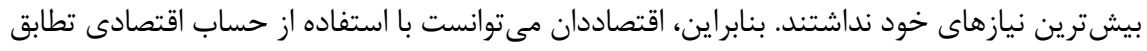

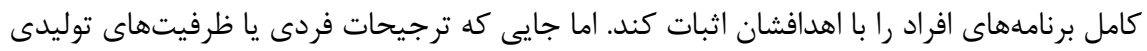

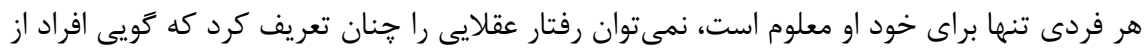

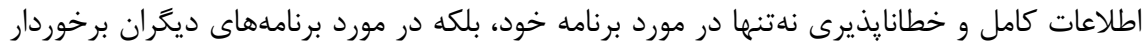

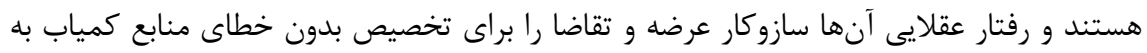

نيازهاى متنوع افراد فعال مي كند (Butos, 1985).

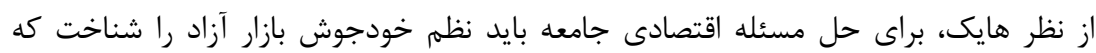

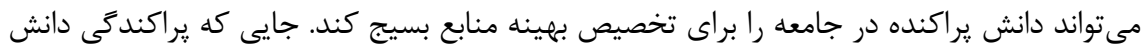

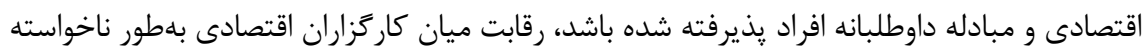

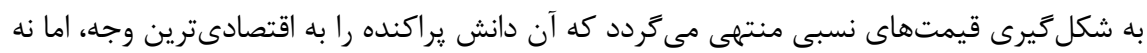

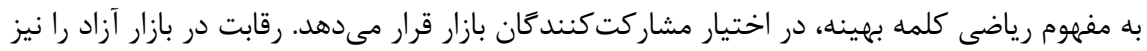

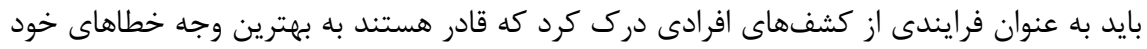

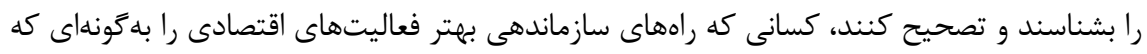

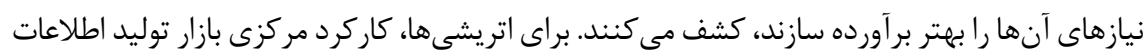

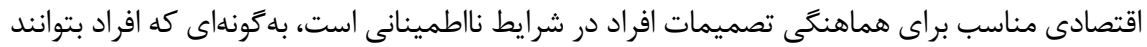

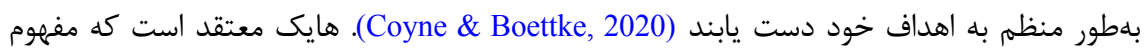


نئوكلاسيكى رقابت آن را از محتواى واقعى خود تهى مى كند، جرا كه اخر همه افراد كيرنده قيمت

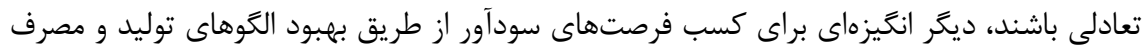

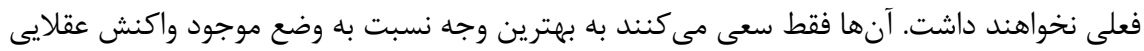

نشان دهند. هايك رقابت را به عنوان يك رويأ كشف فرصتهاى سودآور مىبيند (Hayek, 2002). رفتار عقلايى افراد نيز در جارجوب برداشت هايك از نقش رقابت در اقتصاد تعريف مىشود. آر

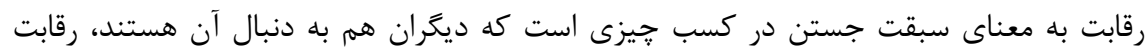
مصرفكنند

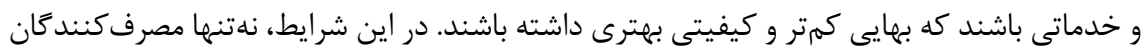

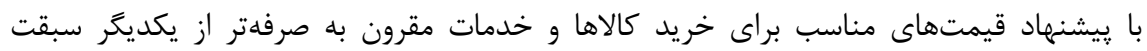
مى جويند، بلكه توليدكنند

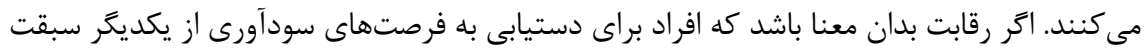

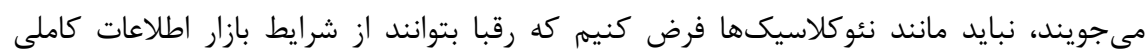
داشته باشند. اين خواست سبقتجويى براى كسب سود بيشتر است كه افراد را وادار مىسازد از دانش و توانايىهاى خاص خود براى غلبه بر ديكران استفاده كنند (غنىنزاد،

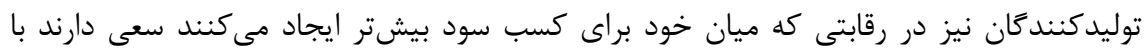

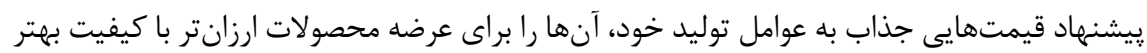

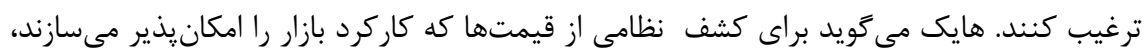
קارهاى جز استفاده از روش آزمون و خطا كه در جار جوب آن همه مشاركت كنند

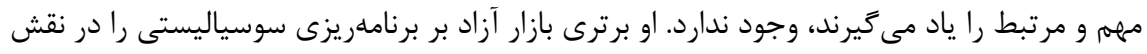
قيمتهاى نسبى براى جمعآورى و يردازش دانش يراكنده در جامعه براى تخصيص مئ منابع كمياب

در حالى كه هايك از رفتار عقلايى تعريف روشنى ارائه نكرده و بيشتر بر ييامدهاى ايده تقسيم

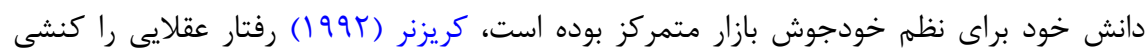

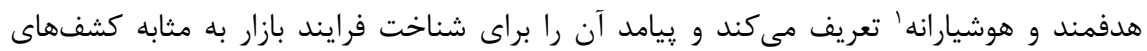

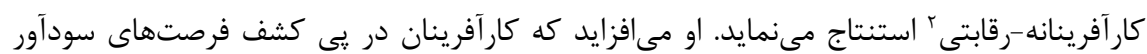


هستند، اما در عين حال نسبت به آن فرصتها غفلت محض' دارند. كارآفرينان معمولاً نمى آنداند كه

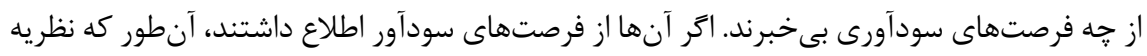

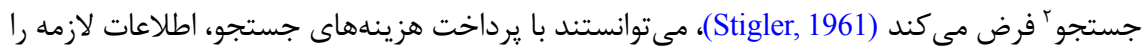

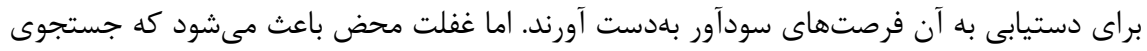

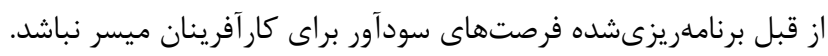

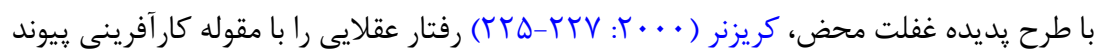

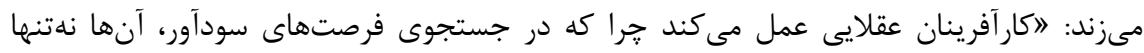

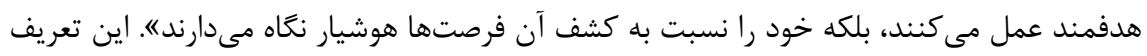

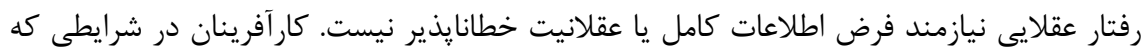

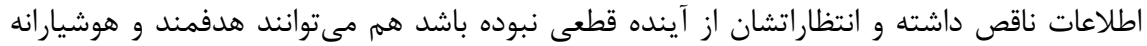

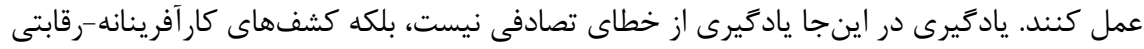

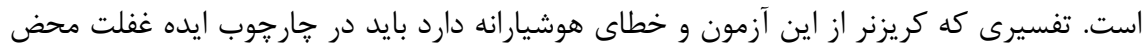

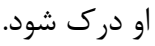

كريزنر بازار رقابتى را فرايند كشفهاى كار آفرينانه-رقابتى تعريف مى كند. از آنجايى كه ورود

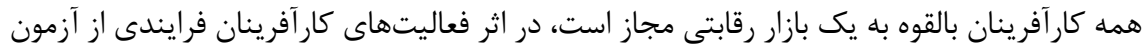

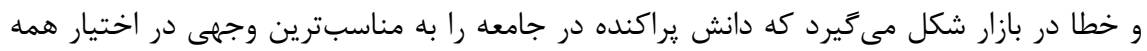

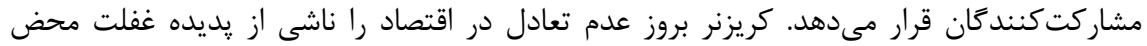

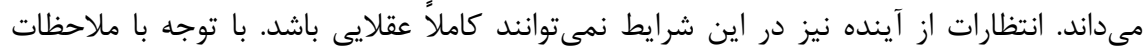

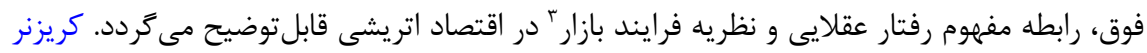

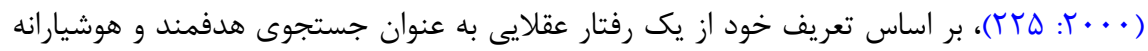

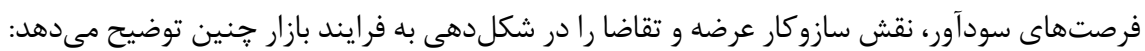

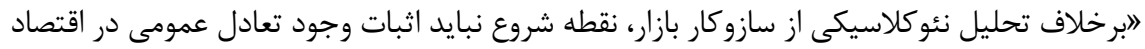

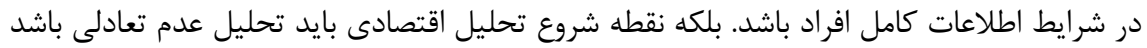

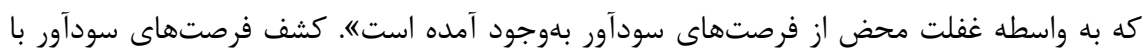
جستجوى هدفمند و هوشيارانه آنها ميسر مىشود و باعث كاهش شكاف عرضه و تقاضا مى كردد.

1. Sheer Ignorance

$19 \Delta$

2. Search Theory

3. Theory of Market Process 
كريزنر اين كشفهاى كارآفرينانه ــ رقابتى را اساس تحليل خود از نقش سازوكار عرضه و تقاضا در

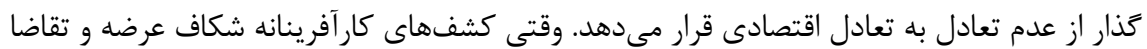
را كاهش مى دهند، قيمتهاى تعادلى ناشى از تسويه بازار تصميمات مربوط به عرضه و تقاضا را بهتر هماهنَ مى كنند و در نتيجه گرايشهاى تعادلى در اقتصاد ايجاد مىشوند. مباحث كَفتهشده درباره تفسير مكتب اتريشى از رفتار عقلايى و نقش آن در شكل مَيرى فرايند

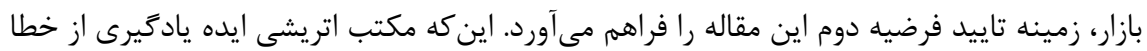
را تا حدى براى درك بهتر سازوكار بازار بكار مى گيرد، يزوهش را قادر مىسازد كه اهميت نظريه

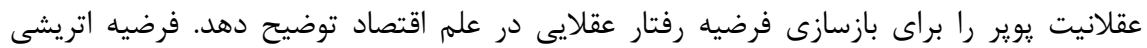

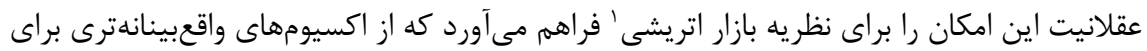

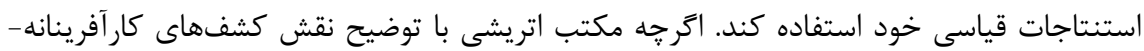
رقابتى در فرايند بازار به درك نقش كليدى يادگيرى از خطادر تحليل فرايند بازار كمك زيادى كردها

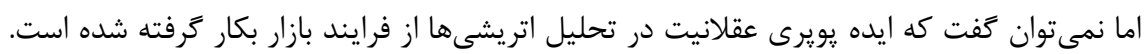

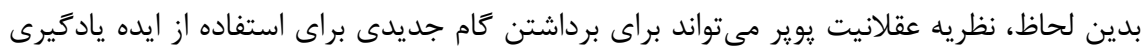

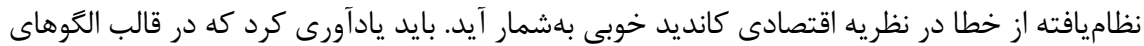

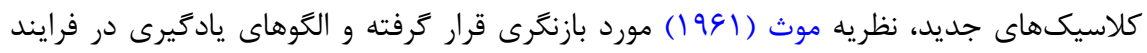

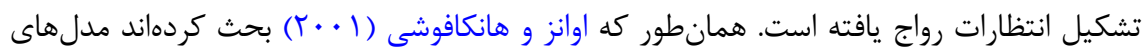

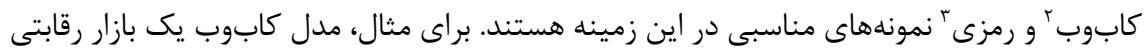
واحدى را فرض مى كند كه داراى يك تاخير زمانى در توليد است. همجنين، مدل فرض مى كند در

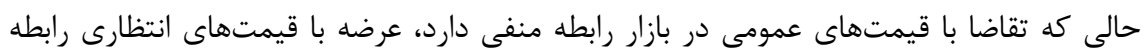

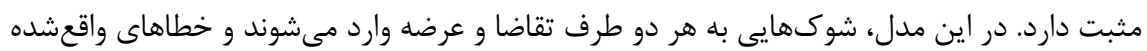
همان خطاهاى تصادفى فرض مىشوند كه در هر دو تابع تقاضا و عرضه، همانند هر مدل ركرسيونى

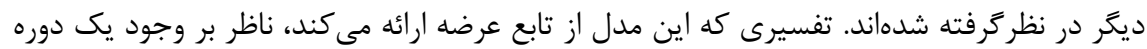
تاخير در توليد است. بنابراين، فرض مىشود تصميمات توليدى يك دوره متكى بر تصميمات توليدى 
امدل كابوب بهطور معمول از ايده كارگزار معرف'، يعنى همه كارگزاران داراى انتظارات واحدى

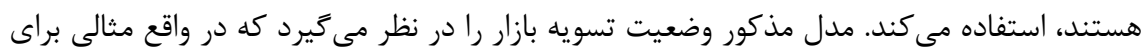
روابط تعادلى موقت بين تقاضا و عرضه است و در آن قيمت جارى به قيمتهاى انتظارى وابسته

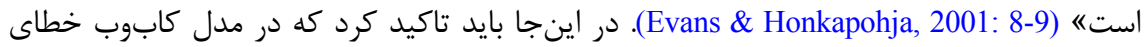
مدل محدود به خطاى تصادفى شده كه در توابع ركرسيونى تقاضا و عرضه منعكس شده است.

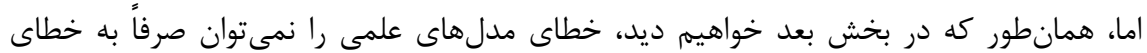

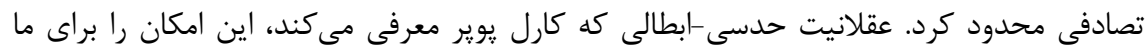

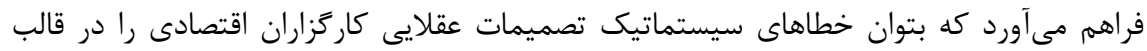
يك يادكيرى سازمانيافته از حدسهاى ابطالشده در نظر گرفت و معناى رفتار عقلايى كارگزاران اقتصادى را كه معطوف به انتظارات از آينده نيز است، در خارجوب ايده يادكيرى از طريق حدس و و ابطال مورد بازتعريف قرار داد.

\section{عقلانيت حدسى - ابطالى يوير و يادكيرى سازمانيافته از خطا}

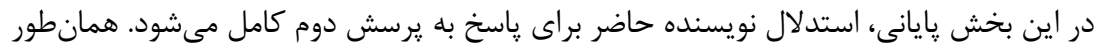

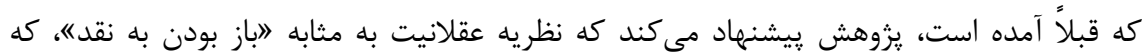

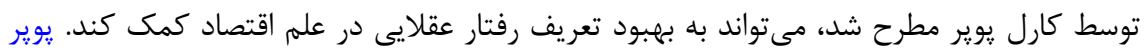

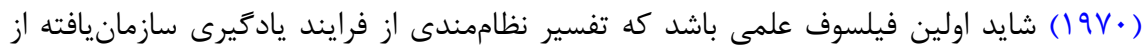

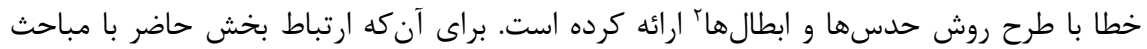

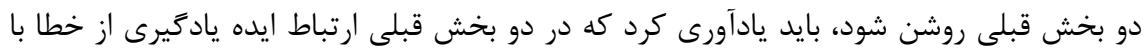
معناى رفتار عقلايى در علم اقتصاد از ديدكاه نئوكلاسيكها و اتريشىها بررسى شد. بخش حاضى حاضر بحث مى كند كه نظريه عقلانيت يوير كه مبتنى بر نظريه دانش علمى اوست، جَّونه مى تواند ايده يادگيرى از خطا را بهطور نظاميافتهاى وارد مفهوم رفتار عقلايى در علم اقتصاد كند. از اين طريق، تفاوت رويكرد حدسى-ابطالى به مفهوم عقلانيت با ديد گاههاى نئوكلاسيكى و اتريشى درباره عقلانيت نيز بهتر آشكار مىشود.

در مورد تفاوت عمدهاى كه نظريه عقلانيت يوير با برداشت نئوكلاسيكى عقلانيت و ارتباط آن با بأ ايده يادكيرى از خطا دارد بايد گفت كه يوير دانش انسانى را كامل نمى داند و خطايذيرى آن رانيز 
به خطاى تصادفى محدود نمى كند. بلكه، مطابق نظريه عقلانيت يوير، خطا بيانكر ابطال حدسى است

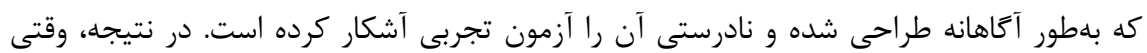
يك حدس (فرضيه) ابطال مىشود، يس دجار خطاى سيستماتيك و اساسى بوده است. ياد خيرى از خطا نيز آموختن از خطاهاى سيستماتيك و نه صرفاً خطاى تصادفى خواهد بود. يوير (9ه9 (9 ())، معتقد است كه باز نخاه داشتن فرضيههاى علمى به نقد باعث كاهش خطاى سيستماتيك مىشود، جرا كه با يادكيرى از هر فرضيه ابطالشده مىتوان فرضيه جديدى ارائه كرد كه خطاى قبلى را نداشته باشد.

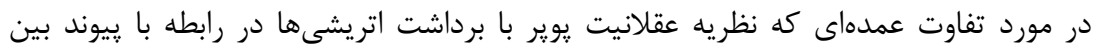

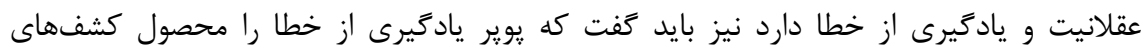
خودجوش در شرايط غفلت محض نمىداند. در حالى كه اتريشىها معتقدند كه وقتى افراد دجار بـار

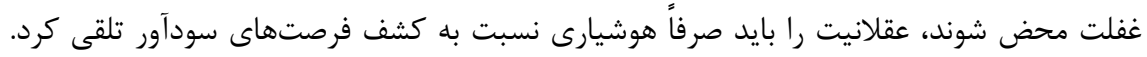
يوير معتقد است كه به لحاظ معرفتشناسى نه جهل كامل (غفلت محض) و نه اطلاعات كامل بيانكر

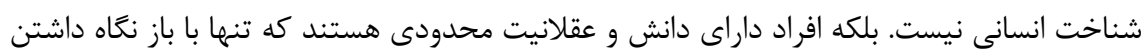
نظاميافته حدسها به نقد و يادكيرى از خطاى آنهاست كه مىتوان محدوديت دانش و عقلانيت را بهتدريج كاهش داد. بهطور خلاصه، در مقابل رويكردهاى نئوكلاسيكى و اتريشى، نظريه دانش

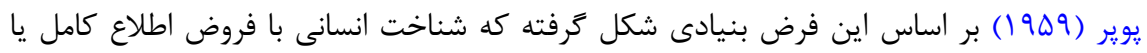

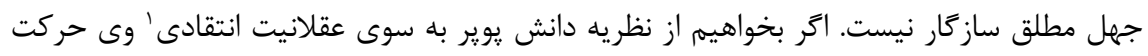
كنيم و آن را براى تعريف مفهوم رفتار عقلايى در علم اقتصاد بكار بريم، بايد توجه داشته باشيم كه كنشكر عقلايى نه از اطلاع كامل برخوردار است، آنطور كه فرضيه نئوكلاسيكى عقلانيت مدعى

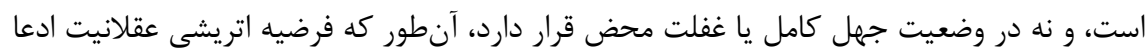

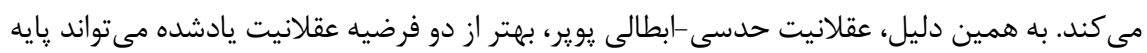
معرفتشناختى `لازم را براى تعريف رفتار عقلايى در علم اقتصاد فراهم آورد.

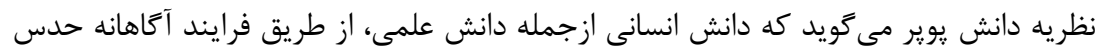

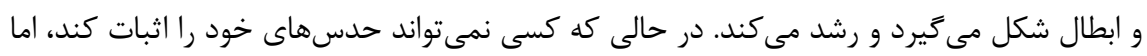

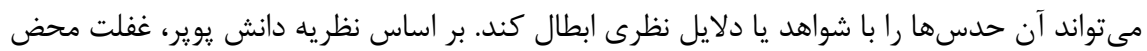
نبايد اساس تحليل دانش انسانى قرار گيرد، جرا كه هر معرفتى از مسئله شروع مىشود و شناخت 
مسئله خود بيانكر حداقلى از آكاهى فرد درباره موضوع مورد بررسى است.

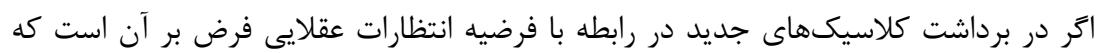

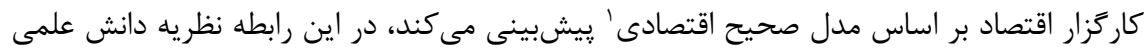
يوبر مى گويد كه هر مدل علمى، ازجمله مدلهاى علم اقتصاد، فرضيههايى (حدسىهايى) هستند كه

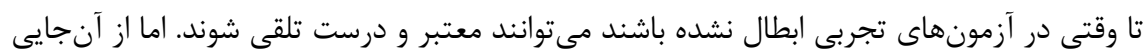

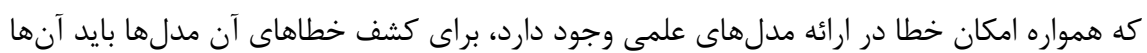

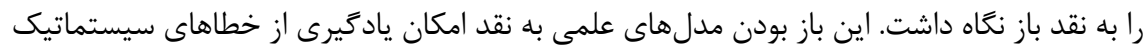

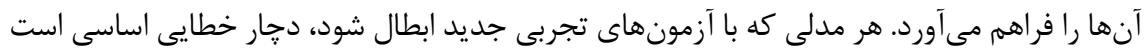

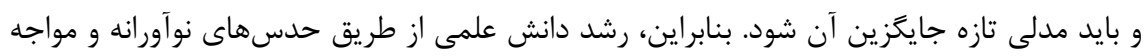

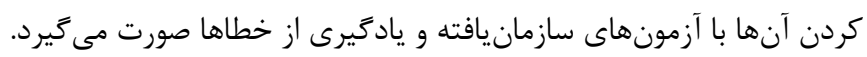

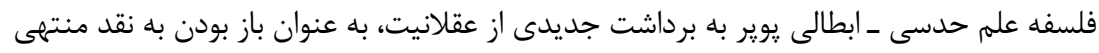

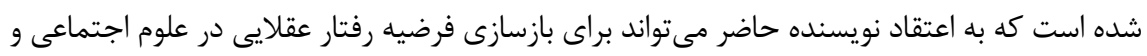

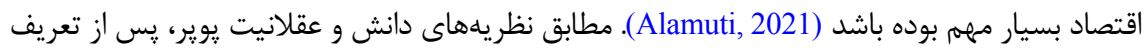

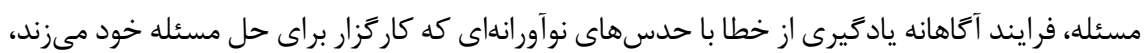
شروع مىشود. اما براى داورى در مورد صحت و سقم آن حدس، كارگزار بايد در يى دلايل ابطال كننده

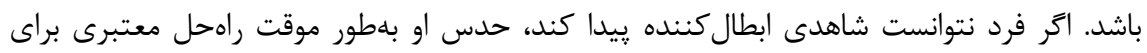
مسئله مورد نظر خواهد بود. بنابراين، در جارجوب تحليل فرايند حدس و ابطال، يوير معناى روشنى براى خطايذيرى دانش و عقل انسانى و ايده يادكيرى سازمانيافته از خطا ارائه مى كند. برداشت يوير

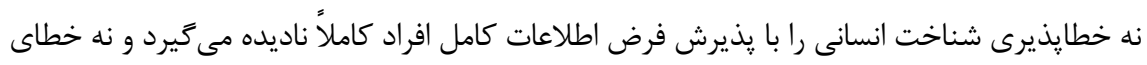

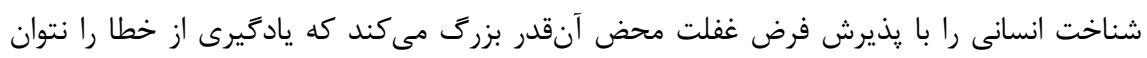

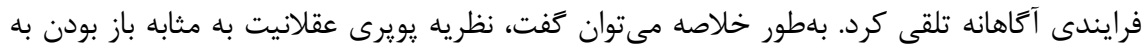

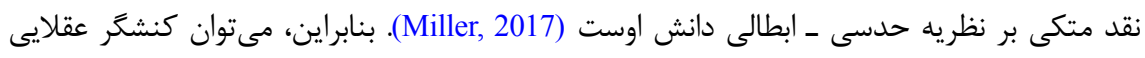

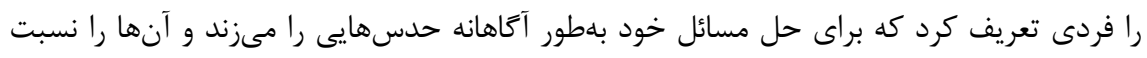

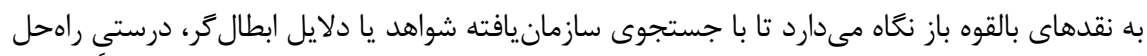

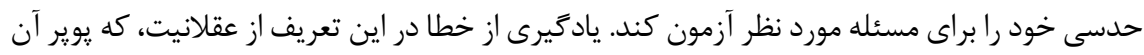
را عقلانيت انتقادى مىنامد، نقش كليدى دارد. فرايند يادكيرى از خطا فرايند سازمانيافته آموختن از ئرئ 
حدسهايى است كه از طريق آزمونهاى سخت ابطال مىشوند. سازوكار يادگيرى و رشد دانش انسانى، حدسهاى نوآورانه و ابطال سازمانيافته آنهاست. در اينجا مىتوان كفت كه توسعه و و تحول موضوع انتظارات عقلايى در قالب الكوهايى كه در مورد يادكيرى مطرح شدهاند با نظريههاى يوير نزديكتر است

.(Evans \& Honkapohja, 2001; Bullard, 1991)

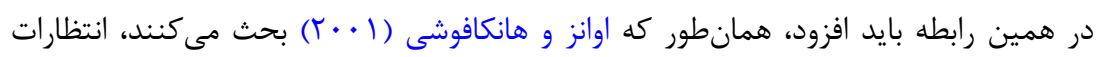
يكى نقش كليدى در الكوهاى اقتصاد كلان بازى مى كند: (1) تصميمات بخش خصوصى مانند

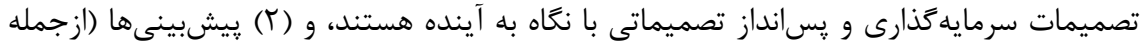

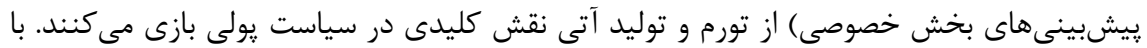

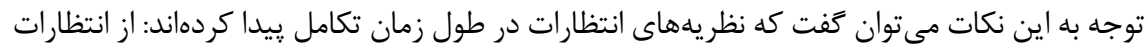

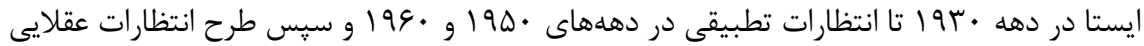

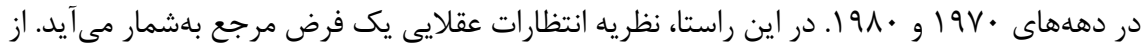

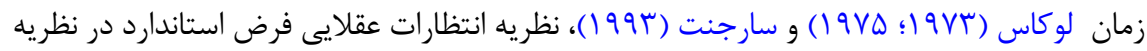
سياست اقتصادى بلهمار آمده است. اين نظريه فرض مى كند كه كارگزاران و سياستخذاران نهتنها از مدل صحيح اقتصادى، بلكه از همه يارامترهاى آن مدل و نيز از اينكه ساير كارگزاران عقلايى رفتار مى كنند و مى دانند كه ديخران مىدانند، دانش و آكاهى كافى دارند. اما در واقع، فرضيه انتظارات

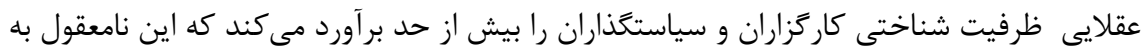
نظر مىرسد. بنابراين، ما به يك مدل مناسب انتظارات متكى بر "اعقلانيت مرزداره' (محدود) نياز داريم. در ياسخ

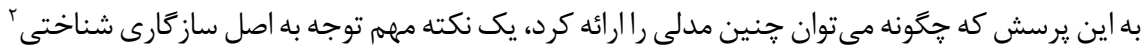

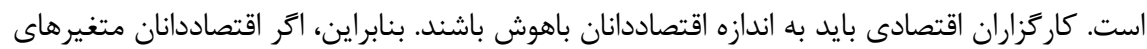
اقتصادى را با استفاده از تكنيكهاى اقتصادسنجى پيشبينى مى كنند، اصل سازگارى شناختى حاكى از آن است كه كار ₹زاران نيز مىتوانند مانند اقتصادسنجها عمل كنند. البته كارَزاران بخش خصى خصوصى و

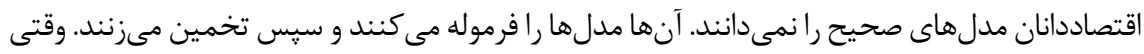

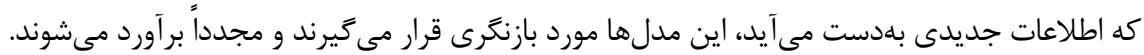

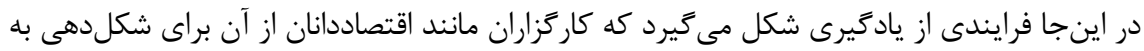

1. Bounded Rationality

2. The Cognitive Consistency Principle 
انتظارات صحيحتر استفاده مى كنند. يادكيرى ممكن است به انتظارات عقلايى رهنمون بشود يا نشود. وقتى كه يك كارگزار بخش خصوصى از يك قاعده يادگيرى ييروى مى كند، امكان بروز نإيايدارى در

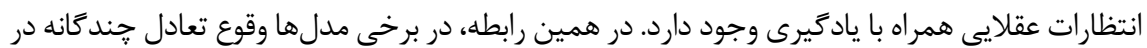

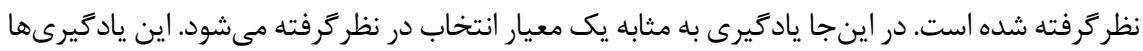
مى توانند يادگيرى يوياى سنتى يا يادگيرى بى بـوقفه باشند. نكته مههم در همين زمينه درك نقش كاربرد عقلانيت محدود در رابطه با مسئله يادگيرى از خطاست (Hommes \& Wagener, 2009). همانطور كه سارجنت (ب9 (199) مطرح مى مكند، كارگزاران اقتصادى در شكلدهى به انتظارات آتى خود مىتوانند دجار خطاى سيستماتيك شوند. مطابق تفسير

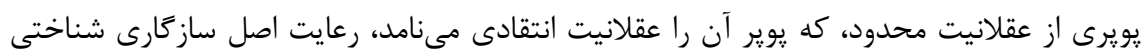

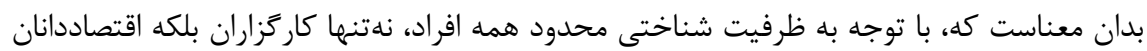

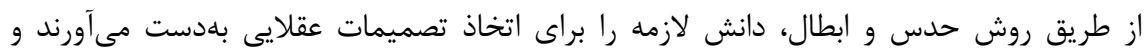
يادگيرى از خطاهاى سيستماتيك (حدسهاى ابطالشده) بخش تفكيكنايذير تصميمات عقلايى بdشمار مى آيد. بررسى كاربرد نظريه عقلانيت يوير، يعنى باز بودن به نقد و يادگيرى از خطا، در تحليل سازوكار

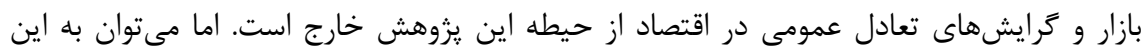

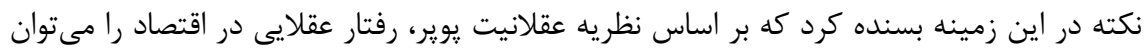

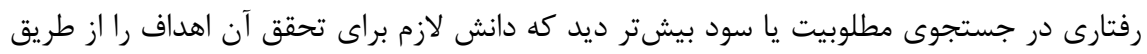

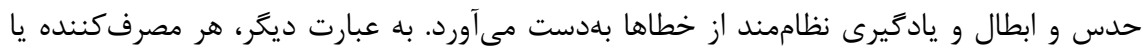

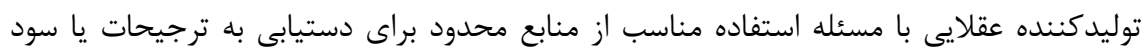

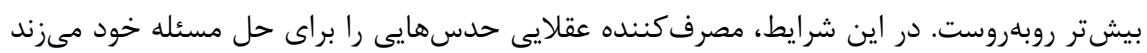

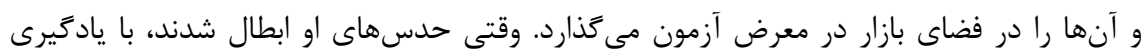

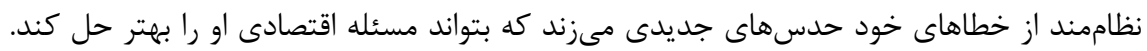

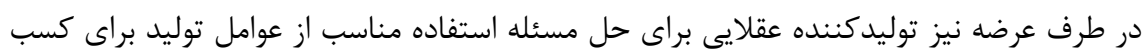

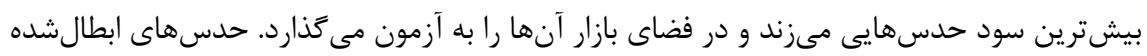
باعث مىشوند كه برنامههاى قبلى توليدكننده مورد تجديد نظر قرار كيرد و راهحل هاى جدئ بديدى برى براى دستيابى به سود بيشتر ارائه شوند. بدين ترتيب، مى توان ديد كه بكارگيرى مفهوم عقلانيت به مثابه بـابه

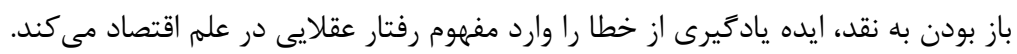




\section{بحث و نتيجه كيرى}

اين يزوهش در يى ياسخ به دو يرسش است: آيا ايده يادگيرى از خطا نقشى در شكل خيرى مفهوم

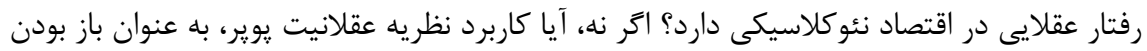

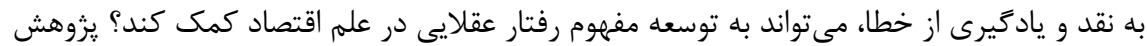
براى ياسخ به اين دو يرسش، دو فرضيه را طرح و بررسى مى كند: فرضيه نخست، مفهوم رفتار عقلايى

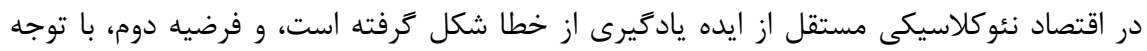
نقدهاى مكتب اتريشى بر فرضيه نئوكلاسيكى رفتار عقلايى، نظريه عقلانيت يورير كانديد خوبى براى

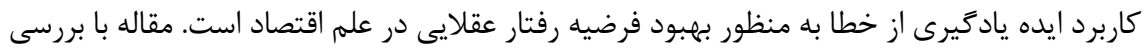
اين دو فرضيه به نتايج زير دست يافته است:

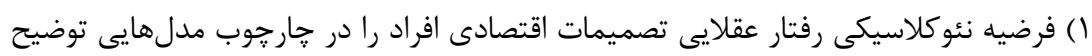
مىدهد كه جايى را براى وقوع خطاى سيستماتيك در انتخاب بهينه ترجيحات مصرفى براى بيشينه كردن مطلوبيت يا انتخاب بهينه عوامل توليد براى بيشينه كردن سود نمى گذارد. اما مدلهاى رياضى انتخاب بهينه مصرفكننده و توليدكننده به درك علم اقتصاد از كاركرد سازوكار بازار آزاد و تعادل عمومى در اقتصاد در وضعيت ايدهآلى كه همه كار تزاران از اطلاعات كامل و انتظارات عقلايى از آينده برخوردار باشند، كمك مهمى كردهاند.

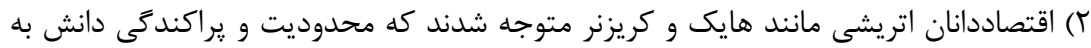
كارگزاران اقتصادى اجازه نمىدهد كه مطابق مدل هاى نئوكلاسيكى رفتار عقلايى و تعادل عمومى ميى مانى

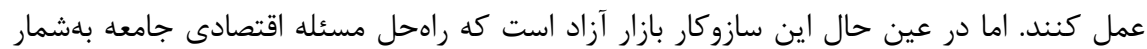

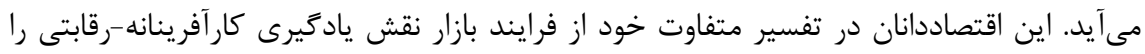

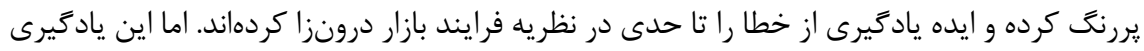

تحت تاثير تاكيد بر بديده غفلت محض است و نمىتواند يك يادكيرى آكاهانه تلقى شودي

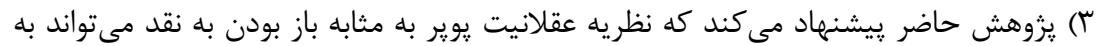

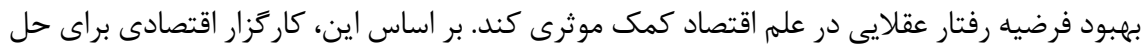

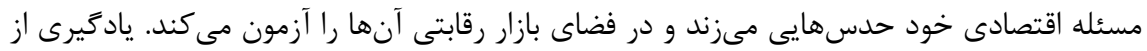

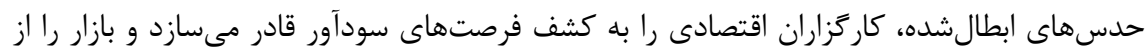

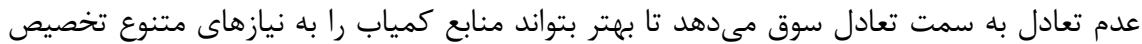




$$
\begin{aligned}
& \text { دهد. به نظر مىرسد كه بر اساس يك تعريف يويرى از رفتار عقلايى بتوان تحليلهاى جديدى درباره } \\
& \text { كارآفرينى، رقابت، انتظارات عقلايى، سازوكار تسويه بازار، و تعادل عمومى ارائه كرد. }
\end{aligned}
$$

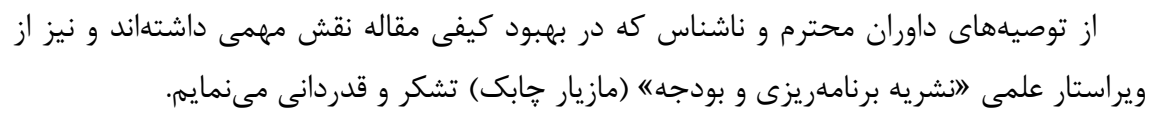

الف) انغَليسى : Chation

Alamuti, M. M. (2021). Critical Rationalism and the Theory of Society: Critical Rationalism and the Open Society Volume 1: Routledge.

Arrow, K. J. (1986). Rationality of Self and Others in an Economic System. Journal of Business, 59(4), 385-399.

Arrow, K. J. (1990). Economic Theory and the Hypothesis of Rationality. In Utility and Probability (pp. 25-37): Springer.

Arrow, K. J., \& Debreu, G. (1954). Existence of an Equilibrium for a Competitive Economy. Econometrica: Journal of the Econometric Society, 265-290. https://doi.org/10.2307/1907353

Benetti, C., Nadal, A., \& Salas, C. (2004). The Law of Supply and Demand in the Proof of Existence of General Competitive Equilibrium: Routledge.

Bullard, J. (1991). Learning, Rational Expectations and Policy: A Summary of Recent Research. Federal Reserve Bank of St. Louis Review, 73(January/February 1991).

Butos, W. N. (1985). Hayek and General Equilibrium Analysis. Southern Economic Journal, 52(2), 332-343. https://doi.org/10.2307/1059619

Coyne, C. J., \& Boettke, P. J. (2020). The Essential Austrian Economics: Fraser Institute

Evans, G. W., \& Honkapohja, S. (2001). Learning and Expectations in Macroeconomics: Princeton University Press.

Farmer, R. E. (1999). The Macroeconomics of Self-Fulfilling Prophecies: MIT Press.

Farmer, R. E. (2010). How the Economy Works: Confidence, Crashes and Self-Fulfilling Prophecies: Oxford University Press.

Feiwel, G. R. (1987). Arrow and the Ascent of Modern Economic Theory: Springer.

Granovetter, M. (2017). Society and Economy: Harvard University Press.

Hart, O. D. (1975). On the Optimality of Equilibrium when the Market Structure is Incomplete. Journal of Economic Theory, 11(3), 418-443. https://doi.org/10.1016/0022-0531(75)90028-9

Hayek, F. A. (1948). The Use of Knowledge in Society. In Individualism and Economic Order: University of Chicago Press. 
Hayek, F. A. (2002). Competition as a Discovery Procedure. Quarterly Journal of Austrian Economics, 5(3), 9-23.

Hommes, C. H., \& Wagener, F. (2009). Bounded Rationality and Learning in Complex Markets. Handbook of Economic Complexity, 87-123.

Jevons, W. S. (1879). The Theory of Political Economy: Macmillan and Company.

Johanson, M. (2004). Resource Allocation under Uncertaintly _ Applications in Mobile Communications. (Doctor of Philosophy). Uppsala University.

Kahneman, D., \& Tversky, A. (1979). Prospect Theory: An Analysis of Decision under Risk. Econometrica, 47(2), 363-391.

Keynes, J. M. (1936). The General Theory of Employment, Interest, and Money: Palgrave Macmillan.

Kirzner, I. M. (1974). Competition and Entrepreneurship: University of Chicago Press.

Kirzner, I. M. (1992). The Meaning of the Market Process: Essays in the Development of Modern Austrian Economics: Routledge.

Kirzner, I. M. (2000). The Driving Force of the Market: Essays in Austrian Economics: Routledge.

Kornai, J. (1971). Anti-Equilibrium; on Economic Systems Theory and the Tasks of Research: North-Holland Publishing Company.

Koslowski, P. (1990). The Categorical and Ontological Presuppositions of Austrian and Neoclassical Economics. General Equilibrium or Market Process: Neoclassical and Austrian Theories of Economics, JCB Mohr, Tübingen.

Lucas Jr, R. E. (1975). An Equilibrium Model of the Business Cycle. Journal of Political Economy, 83(6), 1113-1144. https://doi.org/10.1086/260386

Lucas, R. E. (1973). Expectations and the Neutrality of Money. Journal of Economic Theory, 4(1), 13-34.

Lucas, R. E., \& Sargent, T. J. (1981). Rational Expectations and Econometric Practice (Vol. 2): The University of Minnesota Press.

Marcet, A., \& Sargent, T. J. (1989). Convergence of Least Squares Learning Mechanisms in Self-Referential Linear Stochastic Models. Journal of Economic Theory, 48(2), 337368. https://doi.org/10.1016/0022-0531(89)90032-X

Marshall, A. (1890). Principles of Economics: Mac-Millan.

Miller, D. (2017). Out of Error: Further Essays on Critical Rationalism: Routledge.

Mirowski, P. (1984). Physics and the 'Marginalist Revolution'. Cambridge Journal of Economics, 8(4), 361-379.

Móczár, J. (2017). Arrow-Debreu Model versus Kornai-Critique. Athens Journal of Business and Economics, 3(2), 143-170. https://www.econbiz.de/ppn/886731933

Morgan, J. (2015). What is Neoclassical Economics? Debating the Origins, Meaning and Significance: Routledge.

Muth, J. F. (1961). Rational Expectations and the Theory of Price Movements. Econometrica: Journal of the Econometric Society, 29(3), 315-335. https://doi.org/10.2307/1909635

Pareto, V. (1971). Manual of Political Economy: Oxford University Press.

Popper, K. (1970). Conjectures and Refutations: The Growth of Scientific Knowledge: Routledge.

Popper, K. R. (1959). The Logic of Scientific Discovery: Routledge. 
Radner, R. (1982). Equilibrium under Uncertainty. Handbook of Mathematical Economics, 2(1), 923-1006. https://doi.org/10.1016/S1573-4382(82)02015-3

Ricardo, D. (1932). Principles of Political Economy and Taxation: Bell and Sons.

Robbins, L. (1934). An Essay on the Nature and Significance of Economic Science: Ludwig von Mises Institute.

Sargent, T. J. (1993). Bounded Rationality in Macroeconomics: The Arne Ryde Memorial Lectures. OUP Catalogue. Oxford University Press

Simon, H. A. (1986). Rationality in Psychology and Economics. Journal of Business, 59(4), 209-224.

Stigler, G. J. (1961). The Economics of Information. Journal of Political Economy, 69(3), 213-225. https://doi.org/10.1086/258464

Thaler, R. H. (2015). Misbehaving: The Making of Behavioral Economics: W. W. Norton \& Company.

Thaler, R. H. (2016). Behavioral Economics: Past, Present, and Future. American Economic Review, 106(7), 1577-1600.

Veblen, T. (1900). The Preconceptions of Economic Science. The Quarterly Journal of Economics, 14(2), 240-269. https://doi.org/10.2307/1883770

Viskovatoff, A. (2001). Rationality as Optimal Choice versus Rationality as Valid Inference. Journal of Economic Methodology, 8(2), 313-337. https://doi.org/10.1080/13501780110047336

Von Neumann, J., \& Morgenstern, O. (1953). Theory of Games and Economic Behavior: Princeton University Press.

Walras, L. (1954). Elements of Pure Economics. Translated by William Jaffé: George Allen \& Unwin.

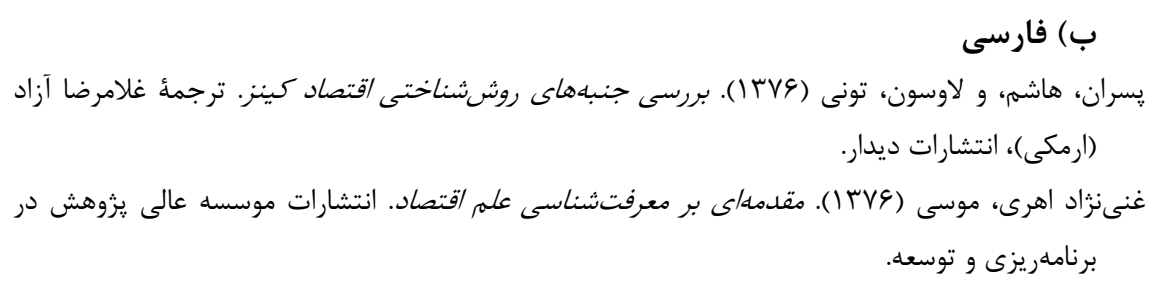

